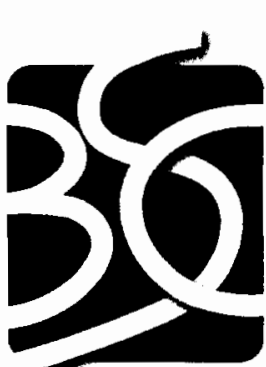

BECHTEL SAIC CONPANULC

QA: QA

Page i

210-3YD-FH00-00100-000-001

April 2005

\title{
Fuel Handling Facility Description Document
}

Prepared for:

U.S. Department of Energy

Office of Civilian Radioactive Waste Management

Office of Repository Development

1551 Hillshire Drive

Las Vegas, Nevada 89134-6321

Prepared by:

Bechtel SAIC Company, LLC

1180 Town Center Drive

Las Vegas, Nevada 89144

Under Contract Number

DE-AC28-01RW12101 


\section{QUALITY ASSURANCE}

The development of this document is subject to the Quality Assurance Requirements and Description (DOE 2004 [DIRS 171539]) requirements. This document was developed in accordance with LP-3.26Q-BSC, System Description Documents, which is based on DOE-STD3024-98, [DIRS 164472] Content of System Design Descriptions.

\section{DISCLAIMER}

This report was prepared as an account of work sponsored by an agency of the United States Government. Neither the United States Government nor any agency thereof, nor any of their employees, nor any of their contractors, subcontractors or their employees, makes any warranty, express or implied, or assumes any legal liability or responsibility for the accuracy, completeness, or any third party's use or the results of such use of any information, apparatus, product, or process disclosed, or represents that its use would not infringe privately owned rights. Reference herein to any specific commercial product, process, or service by trade name, trademark, manufacturer, or otherwise, does not necessarily constitute or imply its endorsement, recommendation, or favoring by the United States Government or any agency thereof or its contractors or subcontractors. The views and opinions of authors expressed herein do not necessarily state or reflect those of the United States Government or any agency thereof. 


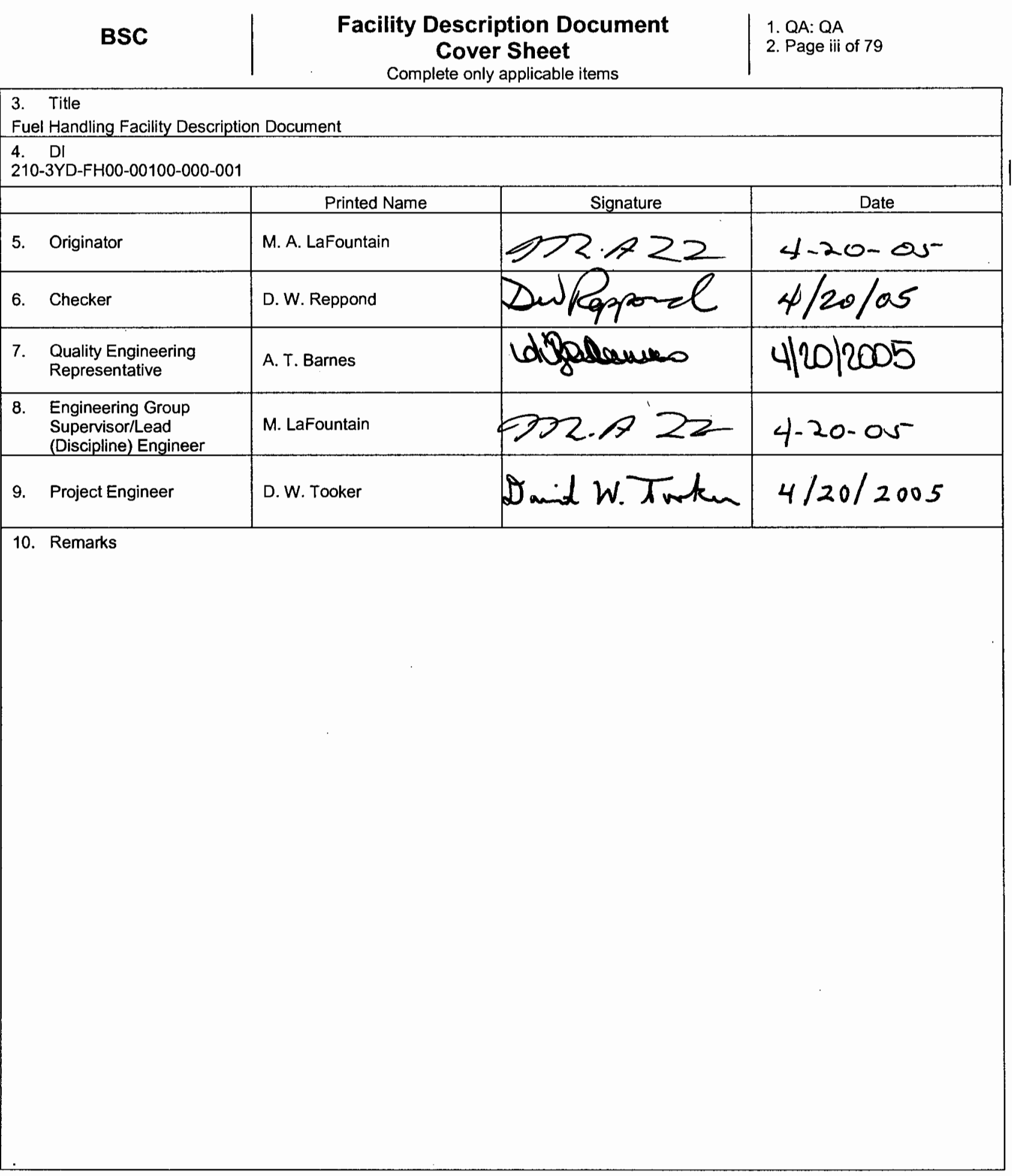




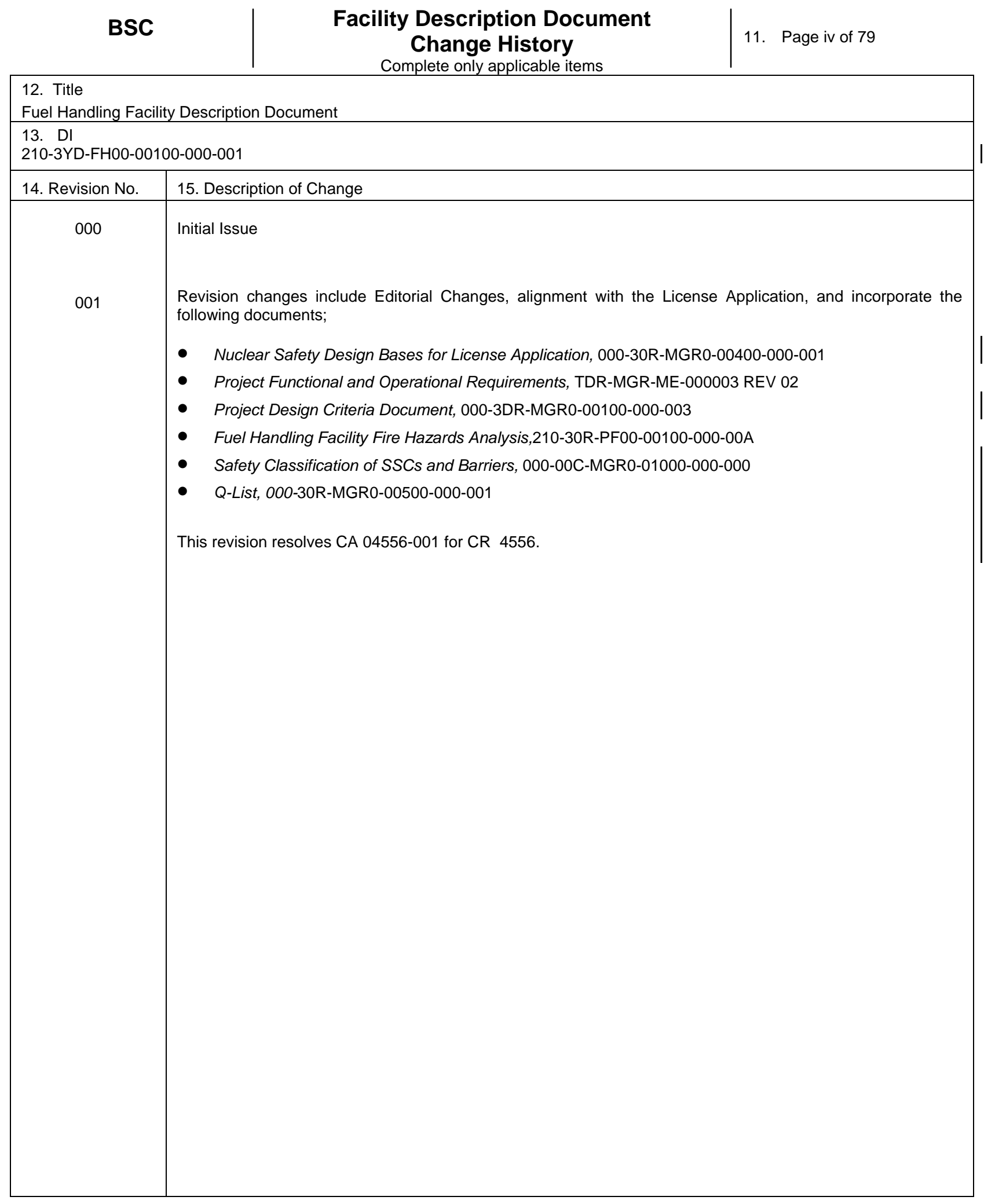




\section{CONTENTS}

Page

ACRONYMS AND ABBREVIATIONS ............................................. vii

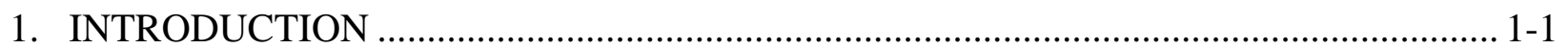

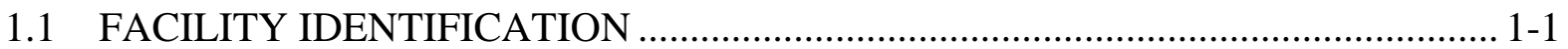

1.2 LIMITATIONS OF THIS FACILITY DESCRIPTION DOCUMENT ........................ 1-3

1.3 OWNERSHIP OF THIS FACILITY DESCRIPTION DOCUMENT ……................. 1-4

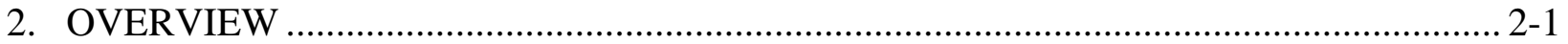

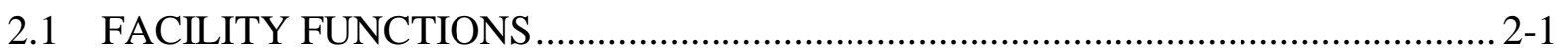

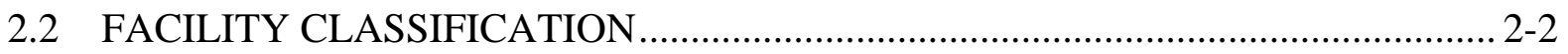

2.3 OPERATIONAL OVERVIEW ……………..................................................... 2-2

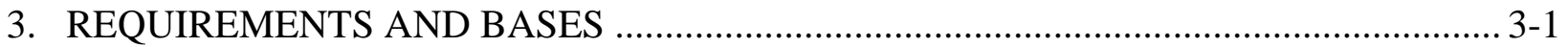

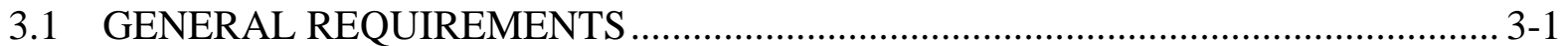

3.2 SPECIFIC REQUIREMENTS AND BASES ……................................................... 3-8

3.3 ENGINEERING DISCIPLINARY REQUIREMENTS ............................................. 3-10

3.4 TESTING AND MAINTENANCE REQUIREMENTS AND BASES ....................... 3-14

3.5 OTHER REQUIREMENTS AND BASES …………......................................... 3-14

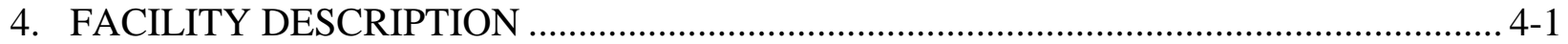

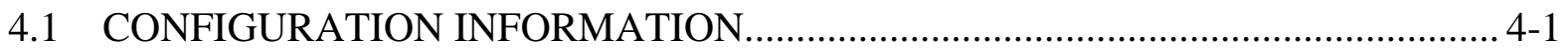

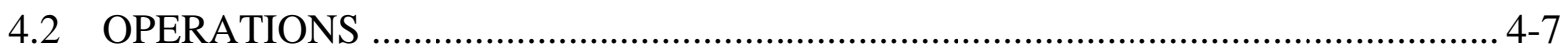

4.3 TESTING AND MAINTENANCE ....................................................................... 4-10

5. REFERENCES …

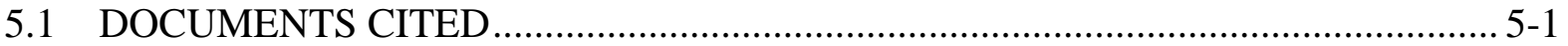

5.2 CODES, STANDARDS, REGULATIONS AND PROCEDURES.............................. 5-3

5.3 DATA TRACKING NUMBERS ………………....................................................... 5-4

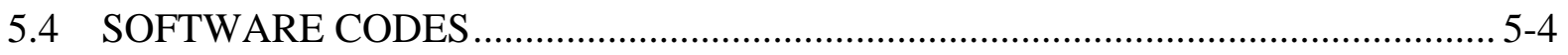

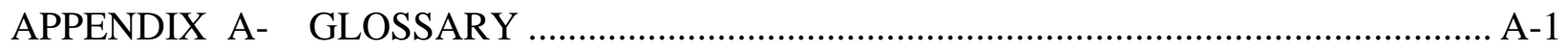

APPENDIX B- OPERATIONAL OVERVIEW, FHF SPACE INVENTORY, AND

LIST OF FACILITY DRAWINGS ……………………..........................

APPENDIX C- LIST OF FACILITY PROCEDURES.............................................................. 


\section{FIGURES}

Page

Figure 4-1.Major Key FHF System Boundaries ........................................................................ 4-4

Figure B-1 Fuel Handling Facility Operations Block Flow Diagram...........................................

Figure B-2 Cask/MSC/WP Preparation System Functional Areas...............................................

Figure B-3 Maximum Inventory of Casks and Waste Packages Within FHF ...........................B-27

\section{TABLES}

Page

Table 4-1. Description of Major FHF System Interfaces .................................................. 4-6

Table B.2.1.4-1 Emplacement and Retrieval System Boundaries within the FHF.................B-19

Table B.3 List of Facility Drawings ……………...................................................... 


\section{ACRONYMS AND ABREVIATIONS}

\section{Acronyms}

as low as is reasonably achievable

BWR boiling water reactor

BSC Bechtel SAIC Company

BDBGM beyond design bases ground motion

DBGM design bases ground motion

DCMIS digital control management information system

DHLW defense high level waste

DIRS document input reference system

DOE U.S. Department of Energy

F\&OR (Project) Functional \& Operational Requirements

FDD Facility Description Document

FHF Fuel Handling Facility

FTM fuel transfer machine

HEPA high-efficiency particulate air (filter)

HLW high-level (radioactive) waste

HVAC heating, ventilation, and air-conditioning

ITS important to safety

ITWI important to waste isolation

MGR Monitored Geological Repository

MSC site-specific cask

MCC motor control center

NRC Nuclear Regulatory Commission

PDC Project Design Criteria Document

PWR pressurized water reactor

SNF spent nuclear fuel

SC safety category

SSC structure, system, or component

TBD to be determined

TBV to be verified

TSR technical safety requirement

WP waste package 


$\begin{array}{ll}\frac{{ }^{2} \mathrm{Abbreviations}}{\mathrm{Cm}^{2}} & \begin{array}{l}\text { degrees centigrade } \\ \text { square centimeters }\end{array} \\ { }^{0} \mathrm{~F} & \text { degrees Fahrenheit } \\ \mathrm{dpm} & \text { disintegrations per minute } \\ \mathrm{mph} & \text { miles per hour } \\ \text { mrem } & \text { millirem (rem } \mathrm{x} 10^{-3} \text { ) } \\ \text { psi } & \text { pounds per square inch } \\ \mathrm{V} & \text { volts } \\ \text { VAC } & \text { volt alternating current }\end{array}$




\section{INTRODUCTION}

The purpose of the facility description document (FDD) is to establish the requirements and their bases that drive the design of the Fuel Handling Facility (FHF) to allow the design effort to proceed to license application. This FDD is a living document that will be revised at strategic points as the design matures. It identifies the requirements and describes the facility design as it currently exists, with emphasis on design attributes provided to meet the requirements. This FDD was developed as an engineering tool for design control. Accordingly, the primary audience and users are design engineers. It leads the design process with regard to the flow down of upper tier requirements onto the facility. Knowledge of these requirements is essential to performing the design process. It trails the design with regard to the description of the facility. This description is a reflection of the results of the design process to date.

Functional and operational requirements applicable to this facility were obtained from the Project Functional and Operational Requirements (F\&OR) document (Curry 2004 [DIRS 170557]). Other requirements that support the design process were taken from higher-level requirements documents such as the Project Design Criteria Document (PDC) (Doraswamy 2004 [DIRS 171599]), the Fuel Handling Facility - Fire Hazard Analysis (BSC 2004 [DIRS 172147]), and the Nuclear Safety Design Bases for License Application (BSC 2004 [DIRS 171512]) The above-mentioned documents address the requirements of the Project Requirements Document (Canori \& Leitner 2003 [DIRS 166275]).

This FDD includes appendices with supporting information. Appendix A provides a glossary of terms; Appendix B provides an overview of operations conducted in FHF, a room by room description of process activities and major equipment, and a listing of key facility drawings; and Appendix C provides a list of facility procedures.

\subsection{FACILITY IDENTIFICATION}

The mission of the FHF is to receive and package commercial, U. S. Department of Energy (DOE) spent nuclear fuel (SNF), and DOE high-level waste (HLW) for emplacement in the repository. The FHF shall be designed to receive and handle the following:

- Transportation casks shipped by truck or rail car

- Commercial SNF

- DOE SNF (except multi-canister overpacks, horizontal dual-purpose canisters, and non-standard fuel)

- DOE HLW

- Dual-purpose canisters containing SNF (canisters transferred to aging only)

- DOE standard canisters

- Empty waste packages (without the availability of the Waste Package and Non Nuclear Receipt Facility)

- Empty or unloaded site-specific casks for waste requiring thermal aging (without the availability of the Waste Package and Non Nuclear Receipt Facility)

- Loaded site-specific casks 
- Navy SNF Canisters.

The FHF will be the first processing facility constructed and operated to receive and package DOE and commercial SNF, and DOE HLW. FHF will be a demonstration scale facility, proving the ability to receive and process SNF and HLW, and will be operational in 2010. Construction of the Canister Handling Facility will be completed next, followed by two, identical Dry Transfer Facilities. The Canister Handling Facility will process only sealed canistered waste (i.e., DOE SNF/HLW for transfer to waste packages or site-specific casks) and will also be operational in 2010. Each Dry Transfer Facility will receive and package DOE and commercial SNF, and DOE HLW plus commercial SNF transported in dual-purpose canisters (requiring canister opening for $\mathrm{SNF} / \mathrm{HLW}$ transfer operations). Both dry transfer facilities will be production scale processing facilities.

The FHF is located on the surface at the North Portal Pad of the geologic repository operations Area site (BSC 2004 [DIRS 171816]). The FHF provides the structural support, space, and layout for embedded systems that can perform the following:

- Prepare loaded transportation casks, empty waste packages, and empty and unloaded site-specific casks for SNF/HLW transfer

- Transfer canistered SNF, canistered HLW, or bare fuel assemblies from loaded transportation casks or site-specific casks to empty waste packages (or empty or unloaded site-specific casks)

- Close (weld, inert, inspect, stress mitigate) loaded waste packages for emplacement

- Close loaded site-specific casks for aging

- Load closed waste packages onto a waste package transporter for emplacement

- Prepare loaded site-specific casks for aging

- Place loaded site-specific casks outside of FHF for pick up by surface transporter for delivery to aging pad

- Prepare unloaded transportation casks for return to the national transportation system

- Prepare unloaded site-specific casks for re-use by the onsite aging system.

The FHF provides a suitable environment for personnel and equipment; protects systems operating in the FHF from natural and induced environments; controls the spread of contamination; and provides radiological protection for personnel. It provides space and layout for industrial and radiological safety systems, operations control and monitoring systems, safeguards and security systems, fire protection systems, ventilation systems, and utility systems. The FHF also provides the required space and layout for maintenance, tool storage, and facilities needed to support essential personnel.

The FHF integrates waste handling systems within its protective structure to support waste processing operations. The facility also provides shielding, suitable layout, and other design features to limit personnel radiation exposure to levels that are as low as is reasonably achievable (ALARA). 
Process systems operating within and around FHF are (see Figure B-1):

- $\quad$ Cask/MSC/WP Preparation System

- $\mathrm{SNF} / \mathrm{HLW}$ transfer system

- Waste package closure system

- Emplacement and retrieval system (operates partially within FHF)

- DOE and commercial waste package system (waste package is routed through FHF)

- Naval SNF waste package system (waste package is routed through FHF)

- SNF aging system (site-specific casks are routed through FHF. SNF aging pads and site-specific cask transport system operate external to FHF)

- Transportation cask receipt and return system

- Cask receipt and return system.

Infrastructure systems operating within FHF are:

- Digital control and management information system

- Environmental/meteorological monitoring system

- Radiation/radiological monitoring system

- Low level radioactive waste generating system

- Low level radioactive waste management system

- Non-radiological waste management system

- Electrical power system

- Electrical support system

- Plant services system

- Communications system

- Fire protection system

- Safeguards and security system

- Heating, ventilation, and air conditioning (HVAC) plant heating and cooling system

- Surface nuclear HVAC system

- $\quad$ Surface industrial HVAC system.

\subsection{LIMITATIONS OF THIS FACILITY DESCRIPTION DOCUMENT}

This FDD may include assumptions, preliminary information, and to be verified (TBV) values, as appropriate to the current level of design development. Additionally, requirements or descriptions that are stated as to be determined (TBD) or are expected at a later phase of the design will be described as such.

At the time this version is approved, the design status is such that the conceptual design has been completed and the Title I preliminary design has been started. As the necessary design documents (calculations, drawings, specifications, and other supporting documents) are completed, the FDD will be updated. 


\subsection{OWNERSHIP OF THIS FACILITY DESCRIPTION DOCUMENT}

This FDD is owned by the FHF Project of Design and Engineering. 


\section{OVERVIEW}

\section{$2.1 \quad$ FACILITY FUNCTIONS}

The F\&OR (Curry 2004 [DIRS 170557]) describes all of the functions that must be | accomplished in the successful execution of the repository mission. With regard to facilities, the F\&OR describes the following functions that repository facilities must perform:

“The MGR shall control all aspects of SNF/HLW handling operations, including material and equipment movement, criticality, quality of sealing, radiological confinement, nuclear material inventories” (Curry 2004 [DIRS 170557], Section 1.1-6).

"The MGR shall provide sufficient space and means to maintain physical services,....” (Curry 2004 [DIRS 170557], Section 1.4.2-3).

"The MGR shall provide sufficient space and means to maintain equipment...." (Curry 2004 [DIRS 170557], Section 1.4.2-4).

"The mission of the MGR is to dispose of SNF/HLW. This involves many operations and activities, which cannot be performed without the provision and maintenance of a robust infrastructure” (Curry 2004 [DIRS 170557], Section 1.4).

“Decontaminate and Decommission Surface Facilities” (Curry 2004 [DIRS 170557], Section 1.3.2). This requirement will be decomposed in a future revision. The FHF design must recognize this functional requirement.

To support the successful execution of the repository mission as stated above, the FHF must carry out the functions listed below.

\subsubsection{Provide Space}

The FHF provides the required space, layout, and structures to support and optimize waste handling operations for expected waste throughputs. This includes adequate working space and environment for personnel, adequate equipment working clearances, and adequate space, layout, and structures for the process and infrastructure systems of the facility. This function is reflected in the F\&OR (Curry 2004 [DIRS 170557], Sections 1.1-6 and 1.4.2-3, 1.4.2-4).

\subsubsection{Protect Structures, Systems, or Components}

The FHF incorporates design features that protect process systems, SNF and HLW, and personnel from phenomena that could cause damage or result in a release of radioactive material. This includes the means for intrusion prevention and detection and physical protection of the material being processed. This function is reflected in the F\&OR (Curry 2004 [DIRS 170557], Section 1.4).

\subsubsection{Support Radioactive Contamination Control and ALARA Objectives}

The FHF incorporates design features to ensure that radioactive contamination resulting from process activities is controlled to protect the environment and that worker and public radiation 
doses are ALARA. In accordance with the F\&OR (Curry 2004 [DIRS 170557], p. 2), these functions “....are not typically allocated to specific functions but are to be used by all facility and system designers in developing their respective designs.”

\subsubsection{Support Closure}

The FHF supports efficient decontamination and decommissioning of surface facilities. This function will be included in a future revision to the F\&OR.

\subsection{FACILITY CLASSIFICATION}

The classification of the FHF is safety category (SC) based on the Q-List (BSC 2004 [DIRS 171190]) and the Nuclear Safety Design Bases for License Application (BSC 2004 [DIRS 171512], Section 6.6.1.4) which states:

"This facility contains SSCs that are ITS; it does not contain SSCs or natural or engineered barriers that are ITWI. The safety category of this facility is SC.”

Additional information regarding system classification is presented in the Q-List (BSC 2004 [DIRS 171190]) and the Safety Classification of SSCs and Barriers (BSC 2004 [DIRS 171668]).

\subsection{OPERATIONAL OVERVIEW}

The FHF is a multi level, reinforced concrete and steel structure in the North Portal area that houses the process systems described in Section 1.1. A detailed operational overview is presented in Appendix B.1. 


\section{REQUIREMENTS AND BASES}

Some of the requirements listed in this section were developed to ensure that the facility functions are satisfied. Where this is the case, the requirement statement references the Section 2 Function that is supported by the requirement. Some requirements listed below result from the need to satisfy a code, standard, or good engineering practice, but they do not directly support the accomplishment of a facility function. All requirements referencing the Nuclear Safety Design Basis for License Application (BSC 2004 [DIRS 171512]) are classified as 10 CFR Part 63 [DIRS 156605] requirements and are located in Section 3.1.1.1. The remaining requirements and associated bases are classified as external compliance unless noted in the comment section. The source of each requirement is shown in brackets at the end of the basis statement.

\subsection{GENERAL REQUIREMENTS}

\subsubsection{Facility Functional Requirements}

Safety requirements, environmental requirements, mission-critical requirements, and general requirements for the FHF are described in this section.

\subsubsection{Safety Requirements}

The safety requirements in this section are nuclear design bases from Table A-1 of the Nuclear Safety Design Basis for License Application (BSC 2004 [DIRS 171512]). Other requirements that address safety issues (such as personnel protection from process industrial hazards) or nuclear criticality safety requirements are presented in the subsequent topical sections below. To avoid repetition, the basis for the following requirements is the same and is only presented once after the first requirement (Section 3.1.1.1.1).

3.1.1.1.1 Requirement: The structure shall: (1) Be designed for the loads associated with a design basis extreme wind speed, as defined in Project Design Criteria Document (BSC 2004 [DIRS 171599] Section 6.1.1.2). (2) Be designed for the loads associated with a design basis tornado maximum wind speed with a corresponding pressure drop and rate of pressure drop, as defined in Project Design Criteria Document (BSC 2004 [DIRS 171599] Section 4.2.2.3.7). (3) Not allow the penetration of Spectrum II tornado missiles, except for the entrance vestibules and the steel structures on the FHF roof (BSC 2004 [DIRS 171471] Sections 6.4.4.1.1 and 9). This requirement supports Function 2.1.2.

Basis: This safety requirement and the requirements under Section 3.1.1.1 were credited in the Nuclear Safety Design Bases for License Application (BSC 2004 [DIRS 171512], Table A-1).

3.1.1.1.2 Requirement: The roof of the structure shall be designed for the loads associated with a volcanic ash fall, as defined in MGR External Events Hazards Screening Analysis (BSC 2004 [DIRS 167266]Section 6.4.5.3).This requirement supports Function 2.1.2.

Basis: Same as for Section 3.1.1.1.1. 


\subsection{Requirement: Removed}

3.1.1.1.4 Requirement: The roof of the structure shall be designed for the loads associated with the maximum observed hourly precipitation event (with a 100-year return period), as defined in Project Design Criteria Document (BSC 2004 [DIRS 171599] Section 6.1.1.1.2). This requirement supports Function 2.1.2.

Basis: Same as for Section 3.1.1.1.1.

3.1.1.1.5 Requirement: Facilities that could be damaged by flooding shall be located above the probable maximum flood elevation or must be appropriately protected from the probable maximum flood (BSC 2004 [DIRS 171599]Section 6.1.2.1). This requirement supports Function 2.1.2.

Basis: Same as for Section 3.1.1.1.1.

3.1.1.1.6 Requirement: The structure shall be designed such that storm water runoff from the maximum observed hourly precipitation event (with a 100-year return period), as defined in Project Design Criteria Document (BSC 2004 [DIRS 171599] Section 6.1.1.1.2), does not enter the structure. This requirement supports Function 2.1.2.

Basis: Same as for Section 3.1.1.1.1.

3.1.1.1.7 Requirement: Flooding of areas of the structure, where moderators shall be strictly controlled due to the presence of fissile material, must be precluded by passive design features such as drains, flood control channels, curbs, elevated processing areas, and walls. This requirement supports Function 2.1.2.

Basis: Same as for Section 3.1.1.1.1.

3.1.1.1.8 Requirement: Closure of airlock doors, shield doors, or other applicable doors on a trolley, SRTC, WP transporter, or other conveyance shall not cause a tipover of the conveyance or cause the conveyance to drop its load. This requirement supports Function 2.1.2.

Basis: Same as for Section 3.1.1.1.1.

\subsection{Requirement: Removed}

3.1.1.1.10 Requirement: The rails and rail anchorage within the structure shall be designed for loading conditions associated with a DBGM-2 seismic event. In addition, it shall be demonstrated that the rails and rail anchorage have sufficient seismic design margin to ensure that a "no derailment" safety function is maintained for loading conditions associated with a BDBGM seismic event. (BSC 2004[DIRS 171470]Table IV-1)

Basis: Same as for Section 3.1.1.1.1.

3.1.1.1.11 Requirement: Surfaces in the load paths through which WPs, standardized DOE SNF canisters, naval SNF canisters, DPCs, transportation casks, or site-specific casks are 
transferred by crane shall be kept free of structures, such as post and curbs, that could puncture a container in the event of a drop. This requirement supports Function 2.1.2.

Basis: Same as for Section 3.1.1.1.1.

3.1.1.1.12 Requirement: The FHF permanent shielding (including shield doors, shield view ports, and viewing windows) shall be designed for loading conditions associated with a DBGM-1 seismic event to demonstrate that there is sufficient seismic design margin to ensure that a "shielding integrity remains intact" safety function is maintained (BSC 2004[DIRS 171470] Table IV-1). This requirement supports Function 2.1.3.

Basis: Same as for Section 3.1.1.1.1.

3.1.1.1.13 Requirement: Portions, parts, subparts, or subsystems, of a non-ITS SSC which, upon failure, could adversely interact with an ITS SSC and prevent its safety function from being performed shall be classified as ITS or redesigned to eliminate the potential unacceptable interaction with the identified ITS SSC. For seismic interactions, portions, parts, subparts, or subsystems, of an otherwise non-ITS SSC shall be classified as ITS and shall be designed to the same seismic DBGM as the ITS SSCs subjected to the potential unacceptable interaction, or the non-ITS SSC may be redesigned to eliminate the potential unacceptable interaction.

Basis: Same as for Section 3.1.1.1.1.

\subsection{Requirement: Removed}

3.1.1.1.15 Requirement: The FHF structure shall be designed for loading conditions associated with a DBGM-2 seismic event. In addition, an analysis shall demonstrate that the FHF structure has sufficient design margin to ensure that a "no structural collapse" safety function is maintained for loading conditions associated with a BDBGM seismic event (BSC 2004[DIRS 171470] Table IV-1).

Basis: Same as for Section 3.1.1.1.1. 
3.1.1.1.16 Requirement: Removed

3.1.1.1.17 Requirement: Removed

3.1.1.1.18 Requirement: Removed

3.1.1.1.19 Requirement: Removed

3.1.1.1.20 Requirement: Removed

3.1.1.1.21 Requirement: Removed

3.1.1.1.22 Requirement: Removed

3.1.1.1.23 Requirement: Removed

3.1.1.1.24 Requirement: Removed

3.1.1.1.25 Requirement: Removed

3.1.1.1.26 Requirement: Removed

3.1.1.1.27 Requirement: Radiation exposure to workers due to inadvertent actuation of doors shall be precluded such that this is not a Category 1 event.

Basis: Same as for Section 3.1.1.1.1.

3.1.1.1.28 Requirement: Removed

3.1.1.1.29 Requirement: Removed

3.1.1.1.30 Requirement: Removed

3.1.1.1.31 Requirement: The severity of potential fires shall not jeopardize the structural integrity of structures where SNF/HLW is present. (BSC 2004 [DIRS 171488] Section 5.1.3.2)

Basis: Same as for Section 3.1.1.1.1.

\subsection{Requirement: Removed}

3.1.1.1.33 Requirement: The exterior walls of the FHF shall not be penetrated or collapsed by an F-16 aircraft crashing into an exterior wall at the speed corresponding to the 95th percentile from a probability distribution estimated from historical F-16 crashes. (BSC 2005 [DIRS 171786] Section 5.1.5)

Basis: Same as for Section 3.1.1.1.1. 


\subsection{Requirement: Removed}

\subsubsection{Environmental Requirements}

Specific environmental requirements for the facility have not been identified at this stage of the design. Environmental requirements for addressing land disturbance from facility construction, facility emissions, water use, or pollution prevention requirements may be needed and will be added to the FDD when these requirements are developed. See Section 3.2.7 for additional Environmental Protection Program requirements

\subsubsection{Mission-Critical Requirements}

3.1.1.3.1 Requirement: The facility shall provide space, layout, and structures for the process systems including personnel access for operations, monitoring, and maintenance. This requirement supports Function 2.1.1.

Performance Acceptance Criterion: The facility shall provide space for process systems necessary to receive transportation casks loaded with commercial, DOE and Naval SNF, and DOE HLW; receive site-specific casks with aged SNF; transfer SNF and HLW to waste packages and empty or unloaded site-specific casks; close waste packages (weld lids in place), transfer waste packages to a waste package transporter for emplacement, close site-specific casks (bolt lid(s) in place), and transfer site-specific casks to a SNF aging system transporter for SNF aging. The applicable process systems are:

- Cask/MSC/WP Preparation System

- $\mathrm{SNF} / \mathrm{HLW}$ transfer system

- WP closure system

- Emplacement and retrieval system

- DOE and commercial waste package system

- Naval SNF Waste Package system

- SNF aging system.

- Cask receipt and return system

- Non nuclear receipt system

Basis: This requirement is implied by the requirements of the Project Functional and Operational Requirements (Curry 2004[DIRS 170557])[Derived].

Comment: Specific space needs for the components and process activities of these process systems are presented in Appendix B.2.

3.1.1.3.2 Requirement: The facility shall provide space, layout, and structures for the infrastructure systems in the facility. This space shall include personnel access for operations, monitoring, and maintenance. This requirement supports Function 2.1.1.

Performance Acceptance Criterion: The facility shall provide space for the following infrastructure systems: 
- Digital control and management information system

- Environmental/meteorological monitoring system

- Radiation/radiological monitoring system

- Low-level radioactive waste generating system

- Low-level radioactive waste management system

- Non-radiological waste management system

- Electrical power system

- Electrical support system

- Plant services system

- Communications system

- Fire protection system

- Safeguards and security system

- HVAC plant heating and cooling system

- Surface nuclear HVAC system

- Surface industrial HVAC system.

Basis: This requirement is derived from the requirements of the Project Functional and Operational Requirements (Curry 2004[DIRS 170557], Section 1.4.1)[Derived].

Comment: Specific space needs for these infrastructure systems are presented in Appendix B.2.

3.1.1.3.3 Requirement: The facility design shall incorporate compartmentalization (tertiary, secondary, primary confinement, and non confinement) as dictated by the needs of process systems and levels of possible contamination from processed material. This requirement supports Function 2.1.3.

Basis: Confinement zones are based on PDC requirements [PDC 4.8.2.2.4].

3.1.1.3.4 Requirement: Design and construction of the surface facilities for the repository shall incorporate standard materials and practices appropriate for the specific building type facilitating a 50-year operational design life. The design shall be defensible in terms of scope, cost, and appearance. This requirement supports Function 2.1.2.

Basis: This requirement is based on good engineering practice and PDC requirements. [PDC 4.2.3.3.1]

3.1.1.3.5 Requirement: The facility shall provide barriers and seals as required to control the spread of contamination within the facility, from the facility. This is an engineering requirement and supports Function 2.1.3.

Basis: This requirement is based on the provision which states that the safety analysis for the geologic repository operations area must consider means to monitor and control the dispersal of radioactive contamination. Workers need to be protected from contamination and the facility must be surveyed on a periodic basis to ensure radiological contamination is within allowable limits (Curry 2004 [DIRS 170557], 2.3-1 \& 2.3-2). Refer to appendix B for expected contamination levels of canisters.

3.1.1.4 General Requirements 
3.1.1.4.1 Requirement: The FHF shall comply with the International Building Code 2000 (ICC 2000 [DIRS 159179]) Use and Occupancy Classification F-2 and Type of Construction 1B. This requirement supports Function 2.1.2.

Basis: This requirement complies with the International Building Code 2000 (ICC 2000 [DIRS 159179]). [PDC 4.2.3.3.2]

3.1.1.4.2 Requirement: The FHF design shall comply with the energy conservation requirements set forth in ANSI/ASHRAE/IESNA 90.1-2001 [DIRS 159548] and the additional energy conservation measures specified in PDC, Section 4.2.3.3.5. This requirement supports Function 2.1.2 and 2.1.3.

Basis: This requirement complies with the cited standard. [PDC 4.2.3.3.5]

3.1.1.4.3 Requirement: FHF access shall comply with the personnel accessibility requirements of ICC/ANSI A117.1-1998 [DIRS 158846], and applicable provisions of the Americans with Disabilities Act of 1990 [DIRS 162264]. This requirement supports Function 2.1.3.

Basis: This requirement complies with the cited standard. [PDC 4.2.3.3.6]

3.1.1.4.4 Requirement: Interior finishes in areas used for processing or storing radioactive materials and those areas having a possibility of radioactive contamination of wall, ceiling, or floor surfaces shall be non-porous for ease of decontamination per NFPA 801-2003 [DIRS 165077], Section3.8. Special protective coatings shall be used in potentially contaminated areas not provided with stainless steel cladding, areas requiring high durability, or liquid containment areas. Coating type and thickness shall be as determined through analysis on an area-by-area basis. This requirement supports Function 2.1.4.

Basis: This requirement establishes the design features that will permit radiation fields to be lowered for operating reasons and will permit more efficient site closure. [PDC 4.2.3.3.8]

\subsubsection{Subsystem and Major Components}

The FHF contains systems that have associated subsystems. However, subsystems are not applicable to the FHF as a facility. Major facility components will include the roof, walls, floors, doors, windows, stairs, etc. Major components located within FHF are listed in Appendix B.

\subsubsection{Boundaries and Interfaces}

3.1.3.1 Requirement: The facility design shall provide appropriate interface with roads and rail lines and size and placement of doors so that interfacing facilities and systems can safely and efficiently access the FHF. This requirement supports Function 2.1.1.

Basis: This requirement is derived from the requirements of the Project Functional and Operational Requirements (Curry 2004[DIRS 170557], Section 1.4.1). [Derived]

Comment: Requirements for interface with the transportation system are presented in interface control documents CRWMS M\&O 1998 [DIRS 101648] and DOE 2002 [DIRS 158398]. 


\subsubsection{Codes, Standards and Regulations}

In addition to the codes, standards, and regulations referenced in the individual requirements of Section 3, comprehensive lists are presented in the PDC (Doraswamy 2004 [DIRS 171599]):

PDC, Section 4.2.2.1, lists the applicable structural codes and standards

PDC, Section 4.2.3.1, lists the applicable architectural codes and standards.

\subsubsection{Operability}

Technical safety requirements (TSRs) have not yet been developed for the FHF, therefore there are no current operability requirements for the FHF. When that TSR is developed this section will be revised to describe the operability requirements for the FHF.

\subsection{SPECIFIC REQUIREMENTS AND BASES}

Hazard analyses are not yet complete, but are assumed to be potentially applicable. This section will be updated for each hazard with information on applicability or non applicability, mitigating and fail safe performance requirements, environments, monitoring, alarms, and interfaces. Additional information is presented in the Preliminary Hazards Analysis for License Application Study (BSC 2004 [DIRS 167313]).

\subsubsection{Radiation and Other Hazards}

Primary capability to shield workers from radiation exposure is covered in Section 3.1.1.1.12.

3.2.1.1 Requirement: The FHF design shall be such that the general dose (total effective dose equivalent) received by occupational personnel does not exceed 5,000 mrem per year maximum. The ALARA total effective dose equivalent dose shall be 500 mrem per year. This requirement supports Function 2.1.3.

Basis: This requirement is based on 10 CFR 20.1201 [DIRS 173264 ] and the Yucca Mountain Project ALARA | design goal. [PDC 4.9.1.2 and 4.9.3]

3.2.1.2 Requirement: To ensure personnel dose is maintained within acceptable limits, the FHF design shall incorporate shielded work areas for the maintenance of cranes, manipulators, power arms and other remotely operated equipment, and shielding for other facility areas that is in accordance with PDC, Table 4.9.1-2. This requirement supports Function 2.1.3.

Basis: This requirement implements the repository ALARA goals. [PDC 4.9.1.3]

3.2.1.3 Requirement: The FHF design shall account for the collection and treatment as low level radioactive waste of any liquids that may intrude into an area where contamination may be present. This requirement supports Function 2.1.3.

Basis: This requirement assures that potential low level radioactive waste is properly managed. Preliminary Hazards Analysis Scenario SI 628 (BSC 2004 [DIRS 167313]). The development of drainage, piping and other low level radioactive collection design details will be developed during detailed design.

\subsubsection{As Low As is Reasonably Achievable}

Design requirements for ALARA considerations are contained in section 3.2.1. 


\subsubsection{Nuclear Criticality Safety}

3.2.3.1 Requirement: The design of the FHF shall ensure that there is no credible criticality event under normal conditions and during Category 1 and 2 event sequences.

Basis: This requirement is based on industry standards for criticality safety. [PDC 4.9.2.2.1]

3.2.3.2 Requirement: Material that could serve as a moderator to enable a self-sustaining nuclear chain reaction (such as water and other hydrogenous materials) shall be controlled in areas of the structure where open waste packages, open transportation casks, open site-specific casks, sealed canisters of DOE SNF (including multi-canister overpacks) or defense HLW, sealed dual-purpose canisters, or uncanistered commercial SNF assemblies may be present. This supports Function 2.1.2 and Requirement 3.1.1.1.7.

Basis: This requirement is based on good engineering practice [Derived]. This requirement expands and clarifies requirement 3.1.1.1.7 to more clearly define the areas and circumstances where moderator control is required.

\subsubsection{Industrial Hazards}

As stated above in Section 3.2, hazard analyses are not yet complete. Industrial hazards will be added to this section in future FDD revisions.

\subsubsection{Operating Environment and Natural Phenomena}

Nuclear design basis requirements from the Pre Closure Safety Analysis that are related to the operating environment and natural phenomena to which the FHF will be subjected are presented in Sections 3.1.1.1.1 through Error! Reference source not found.. Additional requirements related to the operating environment and natural phenomena to which the FHF will be subjected are presented in sections 3.2.5.1 through 3.2.5.3.

3.2.5.1 Requirement: The FHF design shall withstand a frost line depth of 10 inches.

Basis: This requirement is based on site environmental data. [PDC 6.1.1.7]

3.2.5.2 Requirement: The FHF design shall withstand a maximum daily snowfall of 6 inches and a maximum monthly snowfall 6.6 inches.

Basis: This requirement is based on site environmental data. [PDC 6.1.1.1.1]

3.2.5.3 Requirement: The FHF shall withstand and operate in the extreme outside temperature environment of $2^{\circ} \mathrm{F}$ to $116^{\circ} \mathrm{F}$.

Basis: This requirement is based on site environmental data. [PDC 6.1.1.5]

\subsubsection{Human Interface Requirements}

No human interface requirements have been identified for the FHF at this time. As facility human interface requirements are identified, this section will be updated. 


\subsubsection{Specific Commitments}

FHF shall be designed with pollution prevention systems to control air emissions and effluents, minimize water use, and reduce or eliminate discharges to the environment.

Basis: DOE policy is to conduct its operations in an environmentally safe and sound manner, and to perform its activities in compliance with applicable environmental protection requirements. The design shall comply with applicable environmental requirements set forth by federal and state regulations, Executive Orders, and DOE Directives, and requirements derived from environmental permits and corresponding permit conditions.

[PDC 4.1.1.9]

3.2.7.1 Requirement: The repository shall be designed with a goal to reduce energy and water consumption while increasing the use of clean energy sources.

Basis: To meet or exceed the goals of the laws, executive orders and federal regulations for energy efficiency, use of renewable energy, and water conservation at DOE facilities. This requirement pledges compliance with 10 CFR Part 435, Energy: Energy Code for New Federal Commercial and Multi-Family High Rise Residential Buildings [DIRS 173264], that provides the minimum standards for energy efficiency goals in the design of new federal buildings. 10 CFR 435 provides design requirements for building envelopes, electrical distribution systems, and equipment for electric power, lighting, heating, ventilation, air-conditioning, service water heating, and energy management. This is also in conformance with DOE O 430.2A, Departmental Energy and Utilities Management [DIRS 158913], and with 64 FR 30851 [DIRS 104026], Executive Order 13123, that provides the goals for the reduction of greenhouse gas emissions attributed to the energy use of federal buildings.

\subsection{ENGINEERING DISCIPLINARY REQUIREMENTS}

\subsubsection{Civil and Structural}

The civil, structural and architectural design criteria are depicted in Section 4.2 of the PDC (Doraswamy 2004 [DIRS 171599]).

3.3.1.1 Requirement: The design of the FHF reinforced concrete and structural steel components shall be governed by the effects of DBGM-2 earthquake, and will use the ACI 34901 [DIRS 158833] and ANSI/AISC N690-1994, American National Standard Specification for the Design, Fabrication, and Erection of Steel Safety-Related Structures for Nuclear Facilities [DIRS 158835] design codes to ensure that the structures have adequate margins to meet the safety case requirements. Additionally, the FHF shall be evaluated to demonstrate that for a BDBGM ground motion the estimated overall structural performance is adequate to ensure that the seismically induced unacceptable performance is negligible.

Basis: To ensure that an adequate level of design is provided to ensure worker, and public safety the design of the FHF shall meet the requirements of ACI 349-01 [DIRS 158833] for reinforced concrete structures and ANSI/AISC N690-1994 [DIRS 158835] for steel structures. Additionally, the design shall utilize the methods outlined in the Preclosure Seismic Design Methodology for a Geological Repository at Yucca Mountain (BSC 2004 [DIRS 170564] for the design of SSCs important to safety to DBGM-2 seismic levels, and for evaluation to demonstrate seismic margin for beyond design bases ground motion (BDBGM ) for SSCs important to safety.

3.3.1.2 Requirement not Used 
3.3.1.3 Requirement: The FHF earthwork excavation, backfill, compaction and borrow material shall be in accordance with the PDC (Doraswamy 2004 [DIRS 171599] Section 4.2.1.3.1). This supports Function 2.1.2.

Basis: Earthwork is in accordance with the requirement 29 CFR Part 1926 [DIRS 103643]. Engineered backfill and compaction requirements are in accordance with good engineering practice, and the requirements for engineered backfill properties to be equivalent to the insitu alluvium. [PDC 4.2.1.3.1]

3.3.1.4 Requirement: The FHF shall be evaluated for adequate stability (maintain structural and operational integrity) against sliding and overturning effects from the load combinations cited in PDC, Section 4.2.2.4.7.

Basis: The listed load combinations for evaluating sliding and overturning is in accordance with NUREG-0800 (NRC 1987 [DIRS 138431]), Section 3.8.5. Resistance against overturning shall be evaluated by energy approach, and the effect of building sliding shall be evaluated by the use of energy or time history approaches. [PDC 4.2.2.4.7]

3.3.1.5 Requirement: The FHF foundation design shall meet the requirements of NUREG-0800 (NRC 1987 [DIRS 138431], Section 3.8.5).

Basis: This requirement is based on good engineering practices and the requirements of the PDC. [PDC 4.2.2.4.11]

3.3.1.6 Requirement: The structural analysis for the FHF shall use values of design material properties for steel and concrete as found in PDC, Section 4.2.2.6.6.

Basis: This requirement is based on good engineering practice and the requirements of the PDC. [PDC 4.2.2.6.6]

Comment: Criteria for geotechnical design parameters and additional foundation design recommendations have not yet been developed. When these are available, appropriate requirements will be added to the FDD [PDC 4.2.2.6.7].

3.3.1.7 Requirement: The FHF building envelope configurations shall conform to good architectural and structural practices per PDC Section 4.2.3.3.7.

Basis: This requirement invokes the FHF to comply with energy conservation and fire resistive standards and have the capability to withstand and resist high wind and wind-driven missiles.

\subsubsection{Mechanical and Materials}

3.3.2.1 Requirement: FHF structural steel material shall comply with the requirements in PDC, Section 4.2.2.6.1.

Basis: This requirement is based on good engineering practice and the requirements of the PDC. [PDC 4.2.2.6.1]

3.3.2.2 Requirement: FHF concrete and reinforcing steel shall comply with the requirements (compressive strength and ductility respectively) in PDC, Section 4.2.2.6.2.

Basis: Compressive strength specified is reasonable for the area of use. Either ASTM A 706/A 706 M-01 [DIRS 159360] or ASTM A 615/A 615M-01b [DIRS 158033] may be used for reinforcing steel providing that ASTM A 615/A 615M-01b [DIRS 158033] meets the requirements stated for ductility. [PDC 4.2.2.6.2] 
3.3.2.3 Requirement: FHF structural bolting materials shall comply with the requirements (tensile strength, connection type, bolting material, and size) in PDC, Section 4.2.2.6.4.

Basis: This requirement is based on good engineering practice and the requirements of the PDC. [PDC 4.2.2.6.4]

3.3.2.4 Requirement: Welding material used in FHF construction shall be E70XX (AWS D1.1/D1.1M:2002 [DIRS 157203]).

Basis: This requirement is based on good engineering practice and the requirements of the PDC. [PDC 4.2.2.6.5]

\subsubsection{Chemical and Processes}

The requirements in Section 3.1.1.1.7 provide direction on the handling of potential internal flooding from process and infrastructure systems and the control of moderating material from areas of the FHF that might contain fissile material. There are no other chemical and process requirements for the FHF.

\subsubsection{Electrical Power}

There are no electrical power requirements currently identified for the FHF as a facility, however there may be in the future. Electrical requirements for systems operating within FHF are identified in system design documentation.

\subsubsection{Instrumentation and Control}

There are no instrumentation and control requirements currently identified for the FHF as a facility, however there may be in the future. Instrumentation and control requirements for systems operating within FHF are identified in system design documentation.

Doors and hatches are anticipated to have interlocking instrumentation that will regulate access to areas or rooms that may present a radiation hazard to personnel.

\subsubsection{Computer Hardware and Software}

There are no computer hardware and software requirements currently identified for the FHF as a facility, however there may be in the future. Computer hardware and software requirements for systems operating within FHF are identified in system design documentation.

\subsubsection{Fire Protection}

Fire water that could serve as a moderator to enable a self-sustaining nuclear chain reaction shall be controlled from areas of the structure where open waste packages, open transportation casks, open site-specific casks, sealed canisters of DOE SNF (including multi-canister overpacks) or defense HLW, sealed dual-purpose canisters, or uncanistered commercial SNF assemblies may be present. See Section 3.1.1.1.7 and 3.2.3.2.

Basis: Same as for Section 3.1.1.1.1.

3.3.7.1 Requirement not used 
3.3.7.2 Requirement: Partial or full penetration of FHF fire rated walls, floor-ceilings, and roof-ceilings shall be sealed commensurate with the fire rating of the wall or ceiling.

Basis: This requirement implements an assumption used in the fire hazards analysis (BSC 2004 [DIRS 172147]).

3.3.7.3 Requirement: The facility design shall provide space to allow occupants to evacuate the facility in accordance with NFPA 101 [DIRS 165076] and emergency response requirements. Space considerations shall include maximum allowed travel distance, minimum corridor widths, and limitations on common paths of travel. This requirement supports Function 2.1.3.

Basis: This requirement is based on NFPA 101 [DIRS 165076]. [PDC 4.8.1.12]

3.3.7.4 Requirement: A maximum travel distance of 75 feet (NFPA 101 [DIRS 165076], Section 7.6.2) shall be allowed to the next confinement barrier in areas of facilities where accidental breach of a primary confinement system could expose personnel to radioactive material per DOE-STD-1066-99 [DIRS 154954], Fire Protection Design Criteria. The 75-foot travel distance may be exceeded (based on building occupancy requirements) in areas not normally occupied by personnel where plant equipment alone is located. This requirement supports Function 2.1.3.

Basis: This requirement is based on DOE-STD-1066-99 [DIRS 154954]. [PDC 4.2.3.3.3]

3.3.7.5 Requirement: Floors, drains, curbs, ramps or sills shall be sized to accommodate anticipated fire fighting water without flooding SSCs important to safety in all areas where automatic or manual water fire suppression systems are installed. Facility design shall also ensure that firewater discharge in one area does not impact SSCs important to safety in adjacent areas. The size and method of collection of fire suppression water shall be consistent with NFPA 801 [DIRS 165077].

Basis: This requirement limits accumulation of firewater system discharge at an acceptable level to limit damage from firewater flooding. [PDC 4.8.1.16.5]

3.3.7.6 Requirement: The configuration of ladders and stairs in FHF shall be in accordance with NFPA 101 [DIRS 165076] or 29 CFR 1910 [DIRS 103642] as noted in PDC, Table 4.2.3-1. This requirement supports Function 2.1.3.

Basis: This requirement complies with the cited codes and standards. [PDC 4.2.3.3.3]

3.3.7.7 Requirement: The FHF design shall comply with requirements of fire barriers and noncombustible or fire-resistive construction materials as described in the FHF fire hazard analysis (BSC 2004 [DIRS 172147]) and in PDC, Section 4.8.1.19. This requirement supports Function 2.1.2 and 2.1.3.

Basis: This requirement is based on standard industry practice. [PDC 4.2.3.3.4]

3.3.7.8 Requirement: The minimum access width, building to building spacing, for fire fighting apparatus shall be not less than 26 feet where fire hydrants are provided and shall not be 
less than 20 feet in width where there are no hydrants. Access pathways shall not exceed 150 feet in length unless a suitable turnaround is provided.

Basis: This requirement provides acceptable width for the access and operation of fire fighting apparatus. [PDC 4.8.1.5.1]

\subsection{TESTING AND MAINTENANCE REQUIREMENTS AND BASES}

\subsubsection{Testability}

Procedures will be developed to define and describe surveillance, inspection, and testing requirements. The procedures will be based on the final facility configuration.

\subsubsection{Safety Required Surveillances}

Technical safety requirements have not yet been written. Requirements resulting from the technical safety requirements will be added to this FDD in a future revision.

\subsubsection{Non-SAFETY Inspections and Testing}

No specific inspection and testing requirements are needed for the facility.

\subsubsection{Maintenance}

The FHF requirements for maintenance are contained in 3.1.1.3.1, 3.1.1.3.2, and 3.2.1.2.

\subsection{OTHER REQUIREMENTS AND BASES}

\subsubsection{Security and Special Nuclear Materials Protection}

Security and safeguards requirements for the FHF will be established as the vulnerability assessment is performed and the physical protection plan is prepared.

\subsubsection{Special Installation Requirements}

There are no special installation requirements for the facility. The FHF design accommodates the installation of process and infrastructure components.

\subsubsection{Reliability, Availability and Preferred Failure Modes}

There are no unique requirements concerning availability or preferred failure modes applicable to the FHF as a facility. The reliability of the FHF, as a facility, is assured through the application of requirements in Sections 3.3.1, 3.3.2, and 3.3.7.

\subsubsection{Quality Assurance}

The minimum quality assurance requirements for the Office of Civilian Radioactive Waste Management Program are established in the Quality Assurance Requirements and Description document (DOE 2004 [DIRS 171539]). Quality assurance requirements associated with process and infrastructure systems (and associated equipment) operating in the FHF will be identified in system description documents. Quality assurance requirements associated with the FHF (e.g., structure, doors, elevators, and stairways) will be developed and included when available. These include quality assurance requirements related to procurement, fabrication, construction, production, handling, packaging, shipping, storing, cleaning, assembly, inspection, testing, operation, maintenance, repair, modification and decontamination. 
3.5.4.1 Requirement: Design of the FHF shall be conducted in accordance with project design control procedures and the Quality Assurance Requirements and Description document (DOE 2004 [DIRS 171539], Section 3).

Basis: This requirement invokes compliance with the Quality Assurance Requirements and Description document (DOE 2004 [DIRS 171539], Section 3).

\subsubsection{Miscellaneous Requirements}

3.5.5.1 Requirement: The FHF design shall include an assessment of the impact on site land disturbance, water usage, and air emissions.

Basis: This requirement invokes compliance with repository environmental permits. [PDC 4.1.1.9, 4.2.1.2]

3.5.5.2 Requirement: The FHF design shall include architectural features as called out in PDC Section 4.2.3, for plumbing, interior non-load bearing walls, floor finishes, and other items.

Basis: This requirement ensures the facility is finished out in accordance with standard practices. [PDC 4.2.3] 


\section{FACILITY DESCRIPTION}

\subsection{CONFIGURATION INFORMATION}

\subsubsection{Description of Facility}

The FHF is configured to provide the structure, space, and layout necessary to integrate the waste handling process (Section 3.1.1.3.1) and infrastructure systems (Section 3.1.1.3.2) required to receive and repackage SNF and HLW for emplacement in the repository. In accordance with the International Building Code 2000 (ICC 2000 [DIRS 159179]), the FHF is a facility with a use and occupancy classification F-2 and $1 \mathrm{~B}$ type of construction (Section 3.1.1.4.1). The FHF configuration, as currently envisioned, is shown on the drawings listed in Appendix B, Section 3.

The FHF is located in the North Portal area. The FHF building is a multi-level, reinforced concrete and steel frame structure with walls and floors primarily constructed using reinforced concrete. When not required for structural or shielding considerations, appurtenance area exterior walls are constructed of metal siding panels with insulation. The building is designed for a 50-year operational life (Section 3.1.1.3.4). It is adequately separated from other buildings to minimize the effects of structure-structure interactions caused by seismic motion.

No special unique, or one-of-a-kind methodologies are used in the design and analysis of the facility. No unique first-of-a-kind materials are used in the construction of the facility. Consistent with requirements for the design of facilities important to safety, the FHF is designed to withstand loads (maintain structural and operational integrity) imposed by natural phenomena such as earthquakes, extreme winds, tornado winds, tornado-generated missiles, and atmospheric pressure drops (Sections 3.1.1.1.1). This includes loads associated with volcanic ash fall, rain, frost, snowfall, and the affects of extreme temperatures (Sections 3.1.1.1.2, 3.1.1.1.4, 3.2.5.1, 3.2.5.2, and 3.2.5.3). The FHF structure shall employ a no-structural collapse safety function during and after a DBGM-2 seismic event (Section 3.1.1.1.15). Structural fire protection shall comply with the International Building Code 2000 (ICC 2000 [DIRS 159179])(Section 3.1.1.4.1). The FHF is also designed to reduce the probability of being breached by a military aircraft (Sections 3.1.1.1.33). Penetrations of fire rated walls, floor-ceilings, and roof-ceilings are sealed commensurate with the fire rating of the wall or ceiling. As a result, the facility can withstand the potential fires identified in the fire hazards analysis (Section 3.3.7.7). Adequate fire fighting access is provided around the facility exterior (Section 3.3.7.8). A potential fire will therefore not compromise the structural integrity of the facility, its equipment, or any structure in the presence of SNF/HLW (3.1.1.1.31). The facility design incorporates energy conservation measures that satisfy guidelines of ANSI/ASHRAE/IESNA 90.1-2001 [DIRS 159548] (Section 3.1.1.4.2).

The FHF is located above the elevation of a probable maximum flood (Section 3.1.1.1.5). The surrounding storm drainage system design also protects the facility by not permitting storm water runoff to enter the facility (Section 3.1.1.1.6). The FHF design accounts for the collection and treatment as low level radioactive waste any liquids that may intrude into an area where contamination may be present (Section 3.2.1.3). Other design features are used to prohibit introduction of water from outside those areas; including drains, curbs, and penetration seals 
(Section 3.1.1.1.7). The FHF floors, drains, curbs, ramps and sills are sized to accommodate anticipated fire fighting water without flooding SSCs important to safety in all areas where automatic or manual water fire suppression systems are installed. The FHF design also ensures that firewater discharge in one area does not impact SSCs important to safety in adjacent areas (Section 3.3.7.5).

The FHF is constructed primarily of noncombustible reinforced concrete and structural steel materials (Section 3.3.7.7.). The building foundation is a reinforced concrete mat with appropriate footings where required. The foundation design incorporates results of a geotechnical test program that characterizes the subsurface lithology and stratigraphy, wave velocity structure, and static and dynamic material properties. Prior to construction of the foundation, the undocumented fill of the existing North Portal pad will be removed and replaced with approved engineered fill.

Airborne radioactive contamination in the FHF is controlled and minimized by the HVAC system. This control is accomplished by dividing the facility into four confinement zones (primary, secondary, tertiary, and non confinement zones) based on differing degrees of potential contamination (Section 3.1.1.3.3). The three confinement zones and the non-confinement zone are served by nuclear and industrial subsystems, respectively, of the HVAC system in FHF. These subsystems provide environmental conditions suitable for the health and comfort of workers, and minimize the spread of airborne radioactive particulates. FHF is designed to mitigate worker doses from potentially contaminated cells with primary confinement HVAC system operating during Category 1 event sequences. The HVAC system also maintains the environmental conditions suitable for the operation of equipment. The exhaust path to the environment includes two stages HEPA filtration; ITS exhaust fans and exhaust ducting.

The FHF is divided into distinct areas for normal waste processing, and for areas that support these activities. The waste handling support areas include equipment rooms, maintenance areas, tool storage, control areas, and areas needed to support personnel. Waste processing operations in the FHF (cask receipt and return, cask preparation, SNF and HLW transfer, waste package closure, and waste package load out) are conducted in a number of rooms. The airlock doors and shield doors separating these rooms are designed such that premature closure of the doors against a transport vehicle does not cause the transport vehicle and its load to overturn or cause a loss of stability of the load (Section 3.1.1.1.8).

Minor Cask and waste package repairs can be performed in the fuel transfer room (Room 2001), the main transfer room (Room 1003), and the waste package closure cell (Room 2006).

Sharp objects that could result in a breach to a cask or waste package are not located under the load path of cask and waste package handling cranes without appropriate lift height restrictions on the cranes (Section 3.1.1.1.11). FHF is designed to prevent a condition where an SSC failure adversely affects another SSC (Section 3.1.1.1.13). The floors and roofs of these rooms are sufficient to prevent failure in the event a crane collapses or drops a load over a space potentially containing waste forms. Rails for vehicles carrying waste forms are designed to prevent tip over of a vehicle and its associated load during normal operations, abnormal operations, accidents, or DBGM-1 or DBGM-2 events (Section 3.1.1.1.10). The interior finishes of these rooms are selected to facilitate decontamination and decommissioning (Section 3.1.1.4.4). FHF is designed 
to control material that could serve as a moderator to enable a self-sustaining nuclear chain reaction from areas of the structure where open waste packages, open transportation casks, open site-specific casks or sealed canisters may be present (Section 3.1.1.1.7 and 3.2.3.2). FHF will contain a maximum of two loaded waste packages and two loaded casks (see Figure B-3). Descriptions of these rooms are presented in Appendix B.2.

Fuel transfer operations take place by transporting fuel from a fuel transfer bay (Rooms 1004, 1005, and 1006) through the fuel transfer room (Room 2001) to another fuel transfer bay. This transfer between rooms while minimizing the contamination that is spread throughout the facility is made possible via a docking port system.

FHF has a single shielded waste package closure cell (Room 2006) that contains the remote equipment required to seal waste packages prior to emplacement.

The FHF has three operating floor levels. All will be manually accessible via corridors and stairwells. The FHF design complies with the personnel access requirements of the ICC/ANSI A117.1-1998 [DIRS 158846], and applicable provisions of the Americans with Disabilities Act of 1990 [DIRS 162264] (Section 3.1.1.4.3). Stairs and ladders for personnel movement in the building and for access to equipment are designed to incorporate requirements of the Life Safety Code (NFPA 101 [DIRS 165076]) and the Occupational Safety and Health Standards [DIRS 103642], as appropriate (Section 3.3.7.6). The facility design incorporates Life Safety Code requirements for personnel egress, including maximum travel distances (Sections 3.3.7.3 and 3.3.7.4). To meet functional and safety requirements, operating galleries are located adjacent to transfer cells. Operating galleries are separated from the transfer rooms and bays by thick, steelreinforced concrete walls. These shielded walls, with shielded windows and doors, protect personnel who remotely operate the waste transfer systems (Section 3.2.1.1). These areas are also independently ventilated and air-conditioned so personnel can safely control operations without entering radioactive areas, high radiation zones, or contaminated spaces. Work areas shielded to limit personnel dose are also provided for the anticipated maintenance on cranes, manipulators, and power arms (Section 3.2.1.2). Shielding components surrounding waste handling areas, such as walls, doors and windows, are designed to provide the same level of shielding protection during and after a DBGM-1 seismic event (Section 3.1.1.1.12). FHF is designed as to prevent inadvertent actions from exposing workers and causing a Category 1 event sequence (Section 3.1.1.1.27). A steel structure entry and exit vestibule is located at the west end of the FHF. The overall footprint of the FHF is approximately 155 feet by 210 feet, excluding the vestibule. The vestibule is 76 feet by 125 feet.

The FHF has no in-process waste staging areas. However, the FHF provides the means to transfer bare SNF from transportation casks to site-specific casks for staging. Transportation casks and empty waste packages are expected to be delivered on demand and closed waste packages are expected to be removed on demand. SNF requiring aging or off-normal and nonstandard SNF is removed from FHF in site-specific casks and staged at aging pads. The FHF has the capacity to characterize, survey, and close unloaded transportation casks for return to the national transportation system. Trunnion collars removed from waste packages prior to emplacement, are returned to the Warehouse and Non Nuclear Receipt Facility for staging. Further information regarding new waste package, site-specific cask, and trunnion collar staging is presented in non nuclear handling system design documentation. 
The FHF design includes features that support efficient decontamination and dismantlement: (BSC 2004 [DIRS 171599] Section 4.2.3.3.8)

- Reinforced concrete structures, consistent with required stringent seismic design requirements, that facilitate demolition techniques, such as the use of expansive mortar

- Removal paths for, heavy equipment

- Use of smooth coatings or polished stainless steel metal surfaces, where applicable, to facilitate decontamination

- Cracks, crevices, and joints sealed to prevent contamination spread to inaccessible areas

- Minimized use of materials that are susceptible to neutron activation to minimize generation of radioactive waste.

- Use of confinement to contain and minimize the spread of radioactive contamination generated during process operations

- Incorporation of features to contain leaks and spills to minimize the number and extent of contaminated areas.

\subsubsection{Boundaries and Interfaces}

The boundaries and interfaces of the FHF are described in Figure 4-1 and Table 4-1.

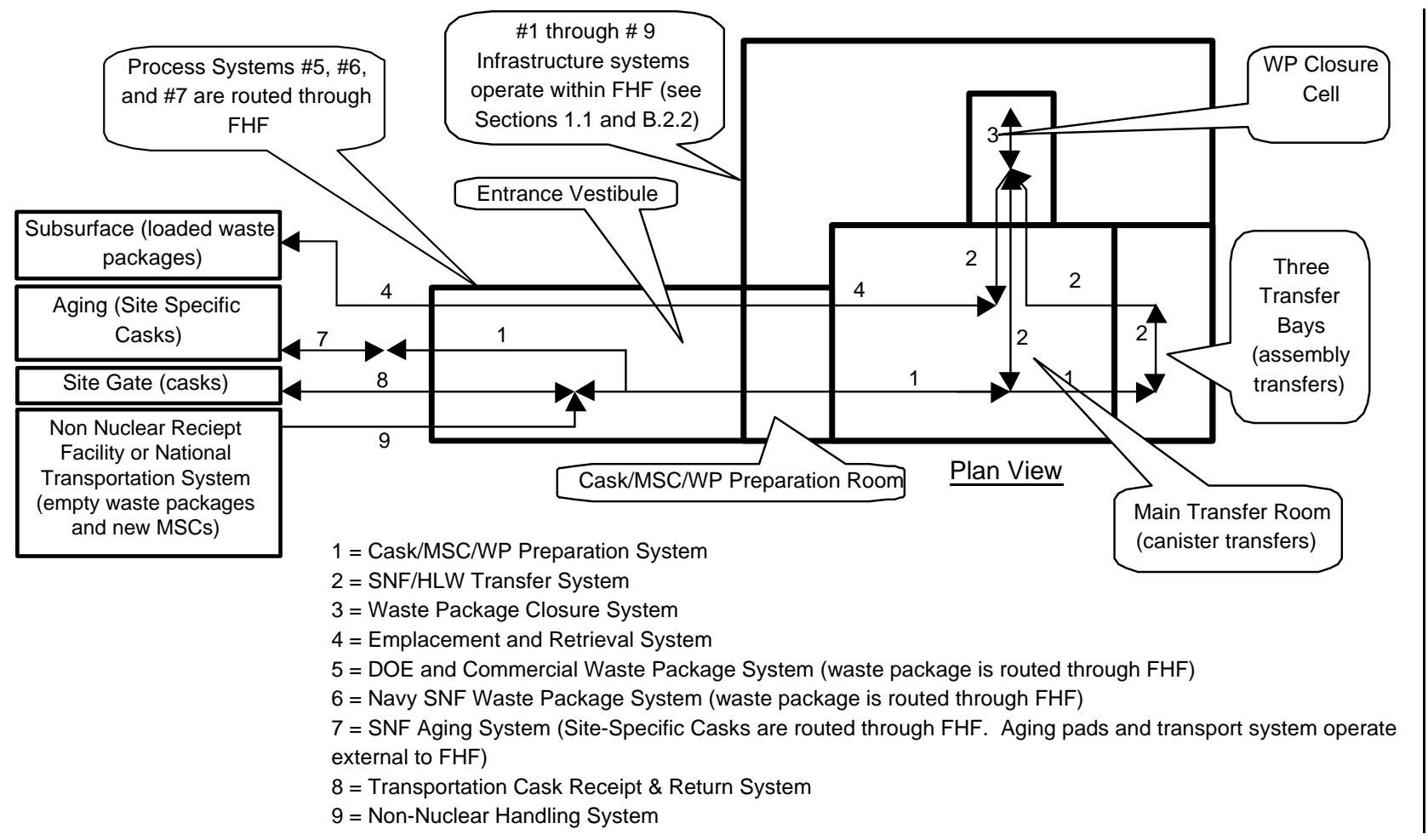

Figure 4-1.Major Key FHF System Boundaries 


\subsubsection{Physical Location and Layout}

The FHF is located in the North Portal area of the repository. A list of FHF drawings, including site layout, facility arrangement, and facility section drawings is presented in Appendix B, section 3. 
Table 4-1. Description of Major FHF System Interfaces

\begin{tabular}{|c|c|c|c|}
\hline Systems Operating Within FHF & Inputs from Interfacing System & Outputs to Interfacing System & Interfacing System \\
\hline \multirow[t]{14}{*}{$\begin{array}{l}\text { Cask/Site Specific Cask/Waste } \\
\text { Package Preparation }\end{array}$} & $\begin{array}{l}\text { Empty waste packages from } \\
\text { National Transportation System }\end{array}$ & & Non-Nuclear Handling \\
\hline & $\begin{array}{l}\text { New, empty Site-Specific Casks } \\
\text { from the National Transportation } \\
\text { System. }\end{array}$ & & Non-Nuclear Handling \\
\hline & $\begin{array}{l}\text { Empty waste packages from } \\
\text { Waste Package Receipt Facility }\end{array}$ & & Non-Nuclear Handling \\
\hline & $\begin{array}{l}\text { New, empty Site-Specific Casks } \\
\text { from Waste Package Receipt } \\
\text { Facility }\end{array}$ & & Non-Nuclear Handling \\
\hline & Loaded Casks from site gate & Unloaded Casks & $\begin{array}{l}\text { Transportation Cask Receipt \& } \\
\text { Return }\end{array}$ \\
\hline & $\begin{array}{l}\text { Loaded Navy Casks from site } \\
\text { gate }\end{array}$ & Unloaded Navy Casks & $\begin{array}{l}\text { Transportation Cask Receipt \& } \\
\text { Return }\end{array}$ \\
\hline & $\begin{array}{l}\text { Loaded Site-Specific Casks (aged } \\
\text { SNF) }\end{array}$ & $\begin{array}{l}\text { Loaded Site-Specific Casks (SNF } \\
\text { requiring aging) }\end{array}$ & SNF Aging \\
\hline & $\begin{array}{l}\text { Unloaded Site-Specific } \\
\text { (previosly used) }\end{array}$ & & SNF Aging \\
\hline & $\begin{array}{l}\text { Loaded Site-Specific Casks ready } \\
\text { to be (closed) for SNF Aging }\end{array}$ & $\begin{array}{l}\text { Loaded Site-Specific Casks with } \\
\text { aged SNF positioned for } \\
\text { SNF/HLW transfer }\end{array}$ & SNF/HLW Transfer \\
\hline & $\begin{array}{l}\text { Unloaded casks/Site-Specific } \\
\text { Casks }\end{array}$ & $\begin{array}{l}\text { Loaded casks/Site-Specific Casks } \\
\text { positioned for } \text { SNF/HLW } \\
\text { transfer }\end{array}$ & SNF/HLW Transfer \\
\hline & Unloaded Navy Casks & Loaded Navy Casks & SNF/HLW Transfer \\
\hline & $\begin{array}{l}\text { Waste package trolleys and } \\
\text { pedestals returned for re-use }\end{array}$ & & SNF/HLW Transfer \\
\hline & & $\begin{array}{l}\text { Empty waste packages positioned } \\
\text { for SNF/HLW transfer }\end{array}$ & SNF/HLW Transfer \\
\hline & & 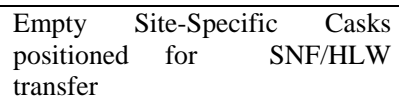 & SNF/HLW Transfer \\
\hline \multirow[t]{9}{*}{ SNF/HLW Transfer } & $\begin{array}{l}\text { Empty waste packages positioned } \\
\text { for SNF/HLW transfer }\end{array}$ & & $\begin{array}{l}\text { Cask/Site-Specific } \\
\text { Preparation }\end{array}$ \\
\hline & 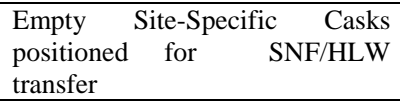 & & $\begin{array}{l}\text { Cask/Site-Specific } \\
\text { Preparation }\end{array}$ \\
\hline & $\begin{array}{l}\text { Loaded casks positioned for } \\
\text { SNF/HLW transfer }\end{array}$ & $\begin{array}{l}\text { Unloaded } \\
\text { Casks }\end{array}$ & $\begin{array}{l}\text { Cask/Site-Specific } \\
\text { Preparation }\end{array}$ \\
\hline & $\begin{array}{l}\text { Loaded Site-Specific Casks with } \\
\text { aged SNF positioned for } \\
\text { SNF/HLW transfer }\end{array}$ & $\begin{array}{l}\text { Loaded Site-Specific Casks ready } \\
\text { to be (closed) for SNF Aging }\end{array}$ & $\begin{array}{l}\text { Cask/Site-Specific } \\
\text { Preparation }\end{array}$ \\
\hline & & $\begin{array}{l}\text { Waste package trolleys and } \\
\text { pedestals returned for re-use }\end{array}$ & $\begin{array}{l}\text { Cask/Site-Specific } \\
\text { Preparation }\end{array}$ \\
\hline & Loaded Navy cask & Unloaded Navy cask & $\begin{array}{ll}\text { Cask/Site-Specific } & \text { Cask/WP } \\
\text { Preparation } & \\
\end{array}$ \\
\hline & $\begin{array}{l}\text { Closed waste package ready for } \\
\text { surveying \& emplacement load- } \\
\text { out }\end{array}$ & $\begin{array}{l}\text { Loaded waste packages with } \\
\text { inner lid in place ready for } \\
\text { closure }\end{array}$ & Waste Package Closure \\
\hline & & $\begin{array}{l}\text { WP on a Pallet placed on the } \\
\text { Transporter For Emplacement }\end{array}$ & Emplacemnet and Retrieval \\
\hline & & $\begin{array}{l}\text { WP Trunnion Collars ready for } \\
\text { return for re-use. }\end{array}$ & $\begin{array}{l}\text { Transportation Cask Receipt \& } \\
\text { Return }\end{array}$ \\
\hline Waste Package Closure & $\begin{array}{l}\text { Loaded waste packages with } \\
\text { inner lid in place ready for } \\
\text { closure }\end{array}$ & $\begin{array}{l}\text { Closed waste package ready for } \\
\text { surveying \& emplacement load- } \\
\text { out }\end{array}$ & SNF/HLW Transfer \\
\hline $\begin{array}{llr}\begin{array}{l}\text { Emplacement } \\
\text { System }\end{array} & \& & \text { Retrieval } \\
\end{array}$ & $\begin{array}{l}\text { Closed waste package ready for } \\
\text { loading onto emplacement pallet }\end{array}$ & & SNF/HLW Transfer \\
\hline
\end{tabular}




\subsubsection{Principles of Operation}

An overview of the process activities that take place in the FHF is presented in Appendix B.1. The process activities that take place in each room, and the process equipment, are presented in Appendix B.2.

\subsubsection{Facility Reliability Features}

The FHF is a highly reliable structure. In addition to incorporating structural design features that permit the facility to withstand earthquakes, tornadoes, and other natural phenomena, the design includes good engineering practices for civil and structural design, mechanical and material design, and fire protection design. These design requirements are presented in Sections 3.3.1, 3.3.2, and 3.3.7.

\subsubsection{Facility Control Features}

Safety management programs, design controls, and administrative controls are developed and documented in safety analysis reports and then incorporated into operating procedures. These procedures, programs, and controls will be developed for the FHF as design matures.

Validation and verification of the controls will be performed through testing programs. This effort will be included in the preparation for startup. More details will be provided in this section as the program and design matures.

Control of the waste handling processes conducted by systems in the FHF is described in system description documents.

\subsection{OPERATIONS}

\subsubsection{Initial Configuration (Pre-Startup)}

Initial configuration activities will be performed prior to startup to ensure that appropriate management and safety procedures and protocols are in place. These activities will include a series of inspections and assessments that will evaluate the completeness of procedures, level of personnel training, and suitability of facilities that will be involved in startup testing and operations.

Pre-startup Facility Inspections-Pre-startup inspections will be performed to verify that facility construction is consistent with facility design.

Management Self-Assessment-Facility management will perform a self-assessment to determine if the facility and operating systems are ready for a more detailed readiness assessment.

Facility Readiness Assessment-A readiness assessment will be performed by a team independent of the facility management to verify that: 
- Work prerequisites have been satisfied.

- Safety documentation has been completed and approved

- Personnel have been suitably trained and qualified

- Implementing documents and management controls are available and approved

- Facility and equipment are available and ready.

Nuclear Regulatory Commission Assessment and Oversight-To be determined later in the design process.

\subsubsection{System Startup}

This section will be completed following design completion. It will summarize the key steps in starting up the facility systems, including sequencing, timing, readiness for the next step, and determining success rate of startup, including references to the governing procedures. At this time, general information is provided in these sections with details to be provided after design completion.

Readiness reviews will be conducted to ensure that objective evidence exists demonstrating satisfaction of work prerequisites, training and qualifying of personnel, and the availability of approved, detailed implementing documents and management controls.

A series of Nuclear Regulatory Commision (NRC) inspection and oversight dry runs will be conducted and monitored by the NRC as an initial start-up activity.

\subsubsection{Normal Operations}

Routine facility inspections and related procedure compliance reviews could be internal reviews conducted by contractor management or external reviews conducted by the DOE or the NRC. These inspections are used during normal system operations to validate safety documentation, training, facility and equipment, and program implementation adequacy.

System integration functions are verified through a readiness review process and are monitored and maintained during normal operations. During normal operations, the individual system functions and systems integration will be monitored and maintained on a routine basis.

Primary facility functions are to provide structural protection to the systems, materials, and personnel within the facility. Walls, doors, and other barriers are provided and maintained to required codes and standards to provide adequate protection to systems, materials, and personnel within the facility under normal and off-normal operations.

Facility maintenance and outages during normal operations are planned and scheduled as needed to conduct facility or system maintenance. Auxiliary or back-up power will be supplied to maintain control equipment and critical functions during maintenance and outages.

During normal operations, all facility infrastructure and process system functions will be routinely monitored and maintained within acceptable thresholds. Safety controls, such as 
interlocks and criticality controls, will be established, monitored, and verified on a continuing basis during normal operations.

\subsubsection{Off-Normal Operations}

Off-normal operations are accommodated by the facility design. As noted above (Section 4.1.5), the facility is highly reliable and can withstand external phenomena. The facility design incorporates compartmentalization for the control of contamination, shielding to limit personnel exposure, and an ITS nuclear HVAC system for confined fuel handling cells to protect facility workers from Category 1 event sequences. To accommodate facility evacuation that may be required during off-normal operations, egress paths are provided and designed to meet requirements of the Life Safety Code (NFPA 101 [DIRS 165076]).

\subsubsection{Facility Shutdown}

Shutdown procedures, standby procedures, and monitoring procedures will be developed for systems operating in the FHF to support system shutdown.

\subsubsection{Safety Management Programs and Administrative Controls}

Integrated safety management system principles are required to provide a safe and controlled working environment for startup operations as well as normal and off-normal facility operations. Some examples of safety management controls and principles include:

- Ensure adequate and correct procedures and work control documents for operating the activity systems are current, approved, and properly controlled

- Perform job safety analyses in accordance with procedures and controls to address hazards implementation into operating and maintenance procedures

- Complete health and safety walk-downs in the operating areas as required to support the activity and ensure deficiencies have been resolved

- Ensure that an adequate startup or restart program is in place to confirm the operability of equipment, viability of procedures and documents, and performance and knowledge of operators

- Perform successful dry runs, as required

- Confirm the formality and discipline of operations is adequate to conduct work safely and that programs are in place to maintain this conduct of operations posture

- Ensure radiological work permits and associated personnel protective equipment is in place to support the activity

- Review environmental regulatory and permit requirements to ensure compliance for the activity

- Continue to maintain voluntary protection program "star" status

- Implement an integrated safety management system prior to startup and maintain the system through the life of the facility

- Establish a senior management review board. 
Safety management programs and controls are developed and documented in documents such as safety analysis reports, and they are incorporated into operations in the form of operating procedures. These procedures will be developed and the programs and controls will be developed as the facility design matures and is finalized. The safety management program in place is the integrated safety management system.

\subsection{TESTING AND MAINTENANCE}

\subsubsection{Temporary Configurations}

Separate testing and maintenance programs and temporary configurations will be developed for systems operating in the FHF.

\subsubsection{Safety-Required Surveillances}

Technical safety requirements will be based on the final facility configuration and its contribution to pre-closure and post-closure performance objectives. A review of these considerations will establish the set of necessary surveillance, inspections, and testing requirements. No surveillances, inspections, and testing requirements have been identified at this time. It is anticipated that there will be a technical safety requirements covering the leak tightness of shielded handling cells. The facility design incorporates features that support leak rate testing of these cells.

\subsubsection{Non-Safety Inspections and Testing}

Procedures will be developed to define and describe non-technical safety requirements surveillances, inspections, and testing requirements. The procedures will be based on manufacturer recommendations and final facility configuration.

\subsubsection{Maintenance}

The FHF design facilitates maintenance activities in the building. The design includes adequate working clearances for component maintenance, equipment laydown and staging areas, equipment access and removal paths, and shielded maintenance enclosures to allow repair, refurbishment, and replacement of equipment, as needed.

Maintenance requirements for the FHF include the development of preventive maintenance and post-maintenance testing processes and programs for testing following modifications. The basic maintenance philosophy is to perform in situ. The major equipment in the facility consists of the entrance vestibule crane (200-ton with 30-ton auxiliary hook mounted on the same bridge and trolley), the main transfer room crane (200-ton with a 30-ton auxiliary hook) a fuel transfer maintenance crane (30 ton), three 15-ton bridge cranes, a fuel transfer machine, a closure cell remote handling crane (3-ton), a waste package turntable, a trunnion-removing machine, master slave manipulators, a remote manipulator system for removing and packaging high efficiency particulate air (HEPA) filters for the fuel transfer room HVAC system, shield doors, and miscellaneous canister/cask grapples. A crane maintenance area is provided at end of the main transfer room for the main transfer room crane. A second crane maintenance area is provided 
above the operator gallery adjacent to the fuel transfer room for the fuel handling machine and 30-ton fuel transfer maintenance crane. A maintenance area is identified on the ground floor adjacent to the waste package closure room for maintenance and repair of master slave manipulators and other removable, maintainable equipment.

Prior to performing in-place, manual maintenance operations, radiation sources such as uncanistered fuel assemblies, canisters, partially-filled waste packages, and opened casks with SNF or HLW are physically removed from the area or covered with shielding to enable safe personnel entry. The shield window stations are provided at various locations to assist in maintenance activities. After removing or shielding radiation sources and/or decontaminating the area, personnel entry is possible to repair failed equipment. Cranes in the main transfer room (Room 1003) and the fuel transfer room (Room 2001) can be moved inside dedicated crane maintenance rooms for repairs.

The welding, testing, and stress mitigation equipment used in the waste package closure process requires periodic adjustments, repairs, and replacements. To facilitate these tasks, the equipment can be remotely removed from the waste package closure room and moved to one of two maintenance areas located adjacent to the waste package closure cell. The equipment in the waste package closure cell can be remotely disengaged and removed from the waste package closure cell to eliminate the need for personnel to enter the waste package closure room during operation. This cell has glove box maintenance capability to prevent spread of contamination during repairs. A shield door is provided between the waste package closure cell and the adjoining maintenance room (Room 2010) (Section 3.2.1.1 \& 3.2.1.2). (BSC 2004 [DIRS171499Further development of the areas of FHF can be found in Appendix B. 
Fuel Handling Facility Description Document

INTENTIONALY LEFT BLANK 


\section{REFERENCES}

\subsection{DOCUMENTS CITED}

101648 CRWMS M\&O 1998. Interface Control Document for the Transportation System and | the Mined Geological Disposal System Surface Repository Facilities and Systems for Mechanical and Envelope Interfaces Between the Surface Facility Operations and the Waste Acceptance and Transportation Office. A00000000-01717-8100-00008 REV 00. Las Vegas, Nevada: CRWMS M\&O. ACC: MOL.19980904.0591.

158398 DOE (U.S. Department of Energy) 2002. U.S. Department of Energy Spent Nuclear Fuel and High-Level Radioactive Waste to the Monitored Geologic Repository. Volume 1 of Integrated Interface Control Document. DOE/RW-0511 Rev. 01. Las Vegas, Nevada: U.S. Department of Energy. ACC: MOL.20020614.0342.

166275 Canori, G.F. and Leitner, M.M. 2003. Project Requirements Document. TER-MGRMD-000001 REV 02. Las Vegas, Nevada: Bechtel SAIC Company.

ACC: DOC.20031222.0006.

167266 BSC (Bechtel SAIC Company) 2004. Monitored Geologic Repository External Events Hazards Screening Analysis. 000-00C-MGR0-00500-000-00A. Las Vegas, Nevada: Bechtel SAIC Company. ACC: ENG.20040712.0004.

167313 BSC (Bechtel SAIC Company) 2004. Preliminary Hazards Analysis for License Application Study. 000-30R-HPYK-00100-000-00A. Las Vegas, Nevada: Bechtel SAIC Company. ACC: ENG.20040610.0002.

170557 Curry, P.M. 2004. Project Functional and Operational Requirements. TDR-MGRME-000003 REV 02. Las Vegas, Nevada: Bechtel SAIC Company. ACC: DOC.20040714.0003.

170564 BSC (Bechtel SAIC Company) 2004. Preclosure Seismic Design Methodology for a Geological Repository at Yucca Mountain. TDR-WHS-MD-000004 REV 01. Las Vegas, Nevada: Bechtel SAIC Company. ACC: DOC.20040827.0011.

171190 BSC (Bechtel SAIC Company) 2005. Q-List. 000-30R-MGR0-00500-000-001. Las Vegas, Nevada: BSC (Bechtel SAIC Company). AAC: ENG20050217.0010.

171470 BSC (Bechtel SAIC Company) 2004. Seismic Analysis for Preclosure Safety. 00000C-MGR0-00700-000-00B. Las Vegas, Nevada: Bechtel SAIC Company. ACC: ENG.20041216.0031.

171471 BSC (Bechtel SAIC Company) 2004. Extreme Wind/Tornado/Tornado Missile Hazard Analysis. 000-00C-WHS0-00100-000-00B. Las Vegas, Nevada: Bechtel SAIC Company. ACC: ENG.20041105.0001.

171488 BSC (Bechtel SAIC Company) 2004. Fire-Induced Event Sequence Analysis. 00000C-MGR0-01300-000-00B. Las Vegas, Nevada: Bechtel SAIC Company. ACC: ENG.20041208.0001.

171499 BSC (Bechtel SAIC Company) 2004. Waste Package Closure System Description Document. 100-3YD-HW00-00100-000-003. Las Vegas, Nevada: Bechtel SAIC Company. ACC: ENG.20040927.0003.

171512 BSC (Bechtel SAIC Company) 2005. Nuclear Safety Design Bases for License Application. 000-30R-MGR0-00400-000-001. Las Vegas, Nevada: Bechtel SAIC 
Company. ACC: ENG.20050308.0004

171539 DOE (U.S. Department of Energy) 2004. Quality Assurance Requirements and Description. DOE/RW-0333P, Rev. 16. Washington, D.C.: U.S. Department of Energy, Office of Civilian Radioactive Waste Management. ACC:

DOC.20040907.0002. Replacement for 171386

171599 BSC (Bechtel SAIC Company) 2004. Project Design Criteria Document. 000-3DRMGR0-00100-000-003. Las Vegas, Nevada: Bechtel SAIC Company. ACC:

ENG.20041124.0001.

171668 BSC (Bechtel SAIC Company) 2005. Safety Classification of SSCs and Barriers. 00000C-MGR0-01000-000-000. Las Vegas, Nevada: Bechtel SAIC Company. ACC: ENG.20050215.0007.

171786 BSC (Bechtel SAIC Company) 2005. Frequency Analysis of Aircraft Hazards for License Application. 000-00C-WHS0-00200-000-00B. Las Vegas, Nevada: Bechtel SAIC Company. ACC: ENG.20050214.0009.

171816 BSC (Bechtel SAIC Company) 2004. Geologic Repository Operations Area North Portal Site Plan. 100-C00-MGR0-00101-000-00C. Las Vegas, Nevada: Bechtel SAIC Company. ACC: ENG.20041007.0004.

172147 BSC (Bechtel SAIC Company) 2004. Fuel Handling Facility Fire Hazard Analysis. 210-30R-PF00-00100-000-00B. Las Vegas, Nevada: Bechtel SAIC Company. ACC: ENG.20041122.0002. 


\subsection{CODES, STANDARDS, REGULATIONS AND PROCEDURES}

LP-3.26Q-BSC, Rev. 1, ICN 4. System Description Documents. Washington, D.C.: U.S. Department of Energy, Office of Civilian Radioactive Waste Management. ACC: DOC.20040520.0006.

10364229 CFR 1910. Labor: Occupational Safety and Health Standards. Readily available.

10364329 CFR 1926. Labor: Safety and Health Regulations for Construction. Readily available.

104026 64 FR 30851. Greening the Government Through Efficient Energy Management. Executive Order 13123. Readily available

138431 NRC (U.S. Nuclear Regulatory Commission) 1987. "Design of Structures, Components, Equipment, and Systems." Chapter 3 of Standard Review Plan for the Review of Safety Analysis Reports for Nuclear Power Plants. NUREG-0800. Washington, D.C.: U.S. Nuclear Regulatory Commission. TIC: 203894.

154954 DOE-STD-1066-99. 1999. Fire Protection Design Criteria. Washington, D.C.: U.S. | Department of Energy. TIC: 249984.

15660510 CFR 63. Energy: Disposal of High-Level Radioactive Wastes in a Geologic Repository at Yucca Mountain, Nevada. Readily available.

157203 AWS D1.1/D1.1M:2002. 2002. Structural Welding Code-Steel. 18th Edition. Miami, | Florida: American Welding Society. TIC: 251437.

158033 ASTM A 615/A 615M-01b. 2001. Standard Specification for Deformed and Plain | Billet-Steel Bars for Concrete Reinforcement. West Conshohocken, Pennsylvania: American Society for Testing and Materials. TIC: $\underline{252480 .}$

158833 ACI 349-01. 2001. Code Requirements for Nuclear Safety Related Concrete | Structures (ACI 349-01). Farmington Hills, Michigan: American Concrete Institute. TIC: 252732.

158835 ANSI/AISC N690-1994. 1994. American National Standard Specification for the Design, Fabrication, and Erection of Steel Safety-Related Structures for Nuclear Facilities. Chicago, Illinois: American Institute of Steel Construction. TIC: 252734.

158846 ICC/ANSI A117.1-1998. 2001. Accessible and Usable Buildings and Facilities. Falls Church, Virginia: International Code Council. TIC: 252742.

158913 DOE O 430.2A. 2002. Departmental Energy and Utilities Management. Washington, D.C.: U.S. Department of Energy. Readily available.

159179 ICC (International Code Council) 2000. International Building Code 2000. Falls Church, Virginia: International Code Council. TIC: 251054.

159360 ASTM A 706/A 706 M-01. 2001. Standard Specification for Low-Alloy Steel Deformed and Plain Bars for Concrete Reinforcement. West Conshohocken, Pennsylvania: American Society for Testing and Materials. TIC: 252911.

159548 ANSI/ASHRAE/IESNA 90.1-2001. Energy Standard for Buildings Except Low-Rise Residential Buildings, I-P Edition. Atlanta, Georgia: American Society of Heating, Refrigerating and Air-Conditioning Engineers. TIC: 253111. 
162264 Americans with Disabilities Act of 1990. Public Law No. 101-336, Readily available. |

164472 DOE-STD-3024-98. 1998. Content of System Design Descriptions. Washington, D.C.: | U.S. Department of Energy. TIC: 254659.

165076 NFPA 101®. 2003. Life Safety Code ${ }^{\circledR} .2003$ Edition. Quincy, Massachusetts: National Fire Protection Association. TIC: 254861.

165077 NFPA 801. 2003. Standard for Fire Protection for Facilities Handling Radioactive Materials. 2003 Edition. Quincy, Massachusetts: National Fire Protection Association. TIC: 254811.

16753810 CFR 20. 2001. Energy: Standards for Protection Against Radiation. Readily available.

17326410 CFR 435. 2005 Energy: Energy Conservation Voluntary Performance Standards for New Buildings; Mandatory for Federal Buildings: ACC: MOL.20050405.0111.

\subsection{DATA TRACKING NUMBERS}

No source data are cited in this document.

\subsection{SOFTWARE CODES}

No software codes are cited in this document. 


\section{APPENDIX A: \\ GLOSSARY}

Basis

Canister

Function

Performance Acceptance Criterion

\section{Requirement}

Statements that refer to design requirements for SSCs and identify why the requirement exists, why it is specified in a particular manner, and why a specified value is used.

The structure surrounding some forms of waste (e.g., high-level radioactive waste immobilized in glass logs or ceramic disks within cans) that facilitates handling, storage, or transportation. Canistered waste will be placed in Waste Packages prior to emplacement.

A function is a statement of the purpose of a system or component.

Performance acceptance criteria are statements that provide verifiable measures of how well the design specification has been achieved or limits against which the actual performance capability of the as-built system can be evaluated.

A specification of what the design solution shall do. Requirement statements should also include a statement of how well the specification is to be achieved so as to permit verification. In some cases, there are several criteria for measuring the success of the achievement of the specification and these would be listed as performance acceptance criteria. 
Fuel Handling Facility Description Document

INTENTIONALY LEFT BLANK 


\section{APPENDIX B: \\ OPERATIONAL OVERVIEW, FUEL HANDLING FACILITY SPACE INVENTORY, AND LIST OF FACILITY DRAWINGS}

\section{B.1 OPERATIONAL OVERVIEW}

The major processing operations performed within FHF are described below. Specific operational overviews for the systems and subsystems contained within the FHF are described in system description documents. The FHF provides three transfer bays. Each bay may be used to receive a cask, site-specific cask, or waste package. For purposes of discussion sections B.1 and B.2 assume waste packages will usually be docked in transfer bay \#1 (Room 1004), casks will be docked in transfer bay \#2 (Room 1005), site-specific casks will be docked in transfer bay \#3 (Room 1006).

\section{B.1.1 Transportation Cask, Site-Specific Cask, and Waste Package Preparation}

Loaded Transportation Casks: FHF is designed to accept the following transportation casks:

- NAC-LWT

- NAC-UMS

- NAC-STC

- HI-STAR

- GA-4
- GA-9

- $\mathrm{TN}-68$

- TS-125

- Naval Rail Cask.

The cask receipt and return system receives transportation casks from the national transportation system. When an SNF/HLW cask shipment arrives by rail or at the repository site security gate (area 30B) the conveyance is moved through the outer security gate by the commercial rail locomotive. The locomotive is disconnected and exits the area through the outer security gate. The outer security gate is closed, establishing a vehicle lock. National Transportation security escorts are responsible for providing physical security until the conveyance is placed within the vehicle lock. Yucca Mountain Project security is responsible for physical security thereafter. Yucca Mountain Project security verifies the tamper-indicating-device number and condition, assesses the overall conveyance condition, and forwards the manifest to the appropriate individual for signature and processing. The conveyance is checked for contraband and explosives. Once the conveyance is released by Yucca Mountain Project security, the inner security gate is opened, the site prime mover is connected to the conveyance, the conveyance is moved through the inner gate into the restricted area, and the inner gate is closed. When a $\mathrm{SNF} / \mathrm{HLW}$ cask shipment arrives by truck, it is handled in a similar manner.

Inside the restricted area, the cask personnel barrier is removed using a portable crane and placed in a lay down area near the cask receipt security station. A radiological swipe survey of the cask and conveyance to comply with the requirements of 10 CFR 20.1906 [DIRS 173264 ] is performed. This survey is required to be completed within three hours of taking receipt of the transportation cask. Any loose contamination is fixed in place or wiped from the contaminated surfaces. Loaded conveyances could go directly to the FHF. However, if a rail conveyance needs to be staged, a site prime mover moves the rail car into the rail yard (area 33A) and parks 
and locks it in place at a predetermined location. The prime mover is disconnected from the rail car and moved out of the rail yard. If a truck conveyance needs to be staged, a site prime mover moves the truck conveyance into area 33b, truck staging area. The prime mover disconnects from the trailer and moves out of the parking area. When required, a site prime mover is used to move the loaded conveyance to the FHF.

When a loaded transportation cask is scheduled for processing at FHF, the import-export trolley is moved along the FHF central rail tracks to a loading position near the inner vestibule door in the FHF entrance vestibule (Room 1001). The vestibule inner door is closed and the outer door opened. The transportation cask conveyance is backed into the vestibule by a site prime mover. The conveyance air brakes are set, wheels blocked, and the site prime mover engine shut off. The outer door closed. The FHF ventilation system design is based on cascading airflow from an area of lower contamination potential to an area of higher contamination potential. Therefore, diesel engine prime movers (truck cabs or rail locomotives) will not be used within the vestibule that will serve as the transportation airlock. The cask receipt and return system handles the site movements of the transportation casks. The cask preparation system includes the handling of the transportation casks within FHF including the removal of the cask from its conveyance.

The personnel barrier (if not already removed) and impact limiters are removed to a stand within the entrance vestibule. Cask tie-downs are released, removed, and placed in a staging location in the entrance vestibule. A surface smear test and radiation survey of the cask impact limiters, tie-downs, and cask is conducted, any loose contamination is wiped clean, a cask condition inspection performed, and the cask up-ended to a vertical position. (Most transportation casks can be up-ended to the vertical position while on the conveyance. However, some casks will be lifted off the conveyance in the horizontal position and up-ended using a tilting frame located within the vestibule area). The cask is lifted from the conveyance, moved to the import-export trolley (previously prepared with a pedestal, if required), lowered onto it, and secured. The trolley is moved to the preparation room (Room 1002) and secured in place. If the conveyance is so designed, the impact limiters and tie-downs are returned to the conveyance and secured in place. If the conveyance is not so designed, the impact limiters and tie-downs are stored in the vestibule. The conveyance is removed from the vestibule.

In Room 1002, the cask outer lid (where applicable) and sample port access cover are removed and stored in room 2013, gas samples are taken and analyzed, and the inner lid bolts are removed and stored. For subsequent SNF transfer between the transfer bays, a lid lifting fixture is installed. The trolley is then moved into the main transfer room (Room 1003).

For subsequent SNF transfer between transfer bays, the loaded cask is lifted from the importexport trolley to a transfer bay trolley previously prepared with the appropriate pedestal (if required). A docking ring is installed and the remaining lid bolts are removed. The transfer trolley with loaded cask is moved into fuel transfer bay \#2 (Room 1005) and adjusted into position for subsequent SNF transfer operations. Following positioning of the loaded cask/sitespecificcask and empty waste package/site-specific caskby the Cask/MSC/WP Preparation System, the SNF/HLW transfer system assumes control and extends a lifting device from the 30ton overhead fuel transfer maintenance crane through the port plug, engages the inner lid of the cask, retracts the lifting device securing the inner lid to the port plug, lifts the port plug/inner lid 
assembly, and moves it to a staging location within room 2001. The SNF/HLW transfer system engages the port docking device with the docking rings of the casksite-specific cask and/or waste package. Transfer of bare fuel assemblies is accomplished using the FTM with appropriate grapple.

When transfer operations are completed, the dose rate in the cask is monitored, the cask interior is visually inspected for remaining items, the docking port plugs with inner lids attached are returned to their respective ports using the fuel transfer maintenance crane (30-ton), the inner lids are released from their respective port plugs and returned to the cask, waste package and/ or sitespecific cask, and the respective port docking devices disengaged. Limited dry wipe decontamination of the exposed unloaded cask or site-specific cask upper surfaces may be performed using a power manipulator on the FTM or the master slave manipulators. The Cask/MSC/WP Preparation System assumes control, returns the empty cask and/or site-specific cask to the main transfer room (Room 1003) for restoration operations. The loaded waste package's lid is secured and the SNF/HLW Transfer System transfers it to room 1003 for closure preparation operations.

For subsequent SNF/HLW canister transfer in the main transfer room (Room 1003), the loaded transportation cask is lifted from the import-export trolley, placed into position at the canister transfer station, and secured for canister transfer operations. A loaded site-specific cask and the transfer trolley of fuel transfer bay \#1 (Room 1004) or of Fuel Transfer Bay \#3 (Room 1006) are also prepared in a similar manner. Empty waste packages and the transfer trolley of room 1004 or room 1006 are prepared in a similar manner.

Contamination levels on the exterior of the canisters are limited to reduce the likelihood of contaminating the main transfer room. The expected operational contamination levels expressed as disintegrations per minute on the canisters are as follows:

$$
\begin{aligned}
& 2200 \mathrm{dpm} / 100 \mathrm{~cm} 2 \text { - beta-gamma } \\
& 220 \mathrm{dpm} / 100 \mathrm{~cm} 2 \text { - alpha } \\
& 20 \mathrm{dpm} / 100 \mathrm{~cm} 2 \text { - transuranics. } \\
& \text { (Curry 2004 [DIRS 170557], 1.1.2.2-1). }
\end{aligned}
$$

Loaded Site-Specific Casks: When a loaded site-specific cask is scheduled for return to the FHF from the SNF aging system aging pad (area 17A), it is delivered in a vertical orientation via the SNF aging system transporter to a point near the entrance vestibule (Room 1001). The gantry crane moves out of Room 1001, lifts the site-specific cask and moves it inside room 1001. From this point site-specific cask preparation follows a similar process as that of a loaded transportation cask.

Empty Site-Specific Casks: If the waste shipment contains high-heat commercial SNF, thermal aging may be required. In this event, commercial SNF is transferred to a site-specific cask for transport to the SNF Aging System aging pad (Area 17A). If available, an unloaded, reusable site-specific cask from Area 17A is moved in a vertical orientation to the entrance vestibule of FHF via the SNF aging system transporter.

FHF may operate without the support of the Waste Package Receipt and Non Nuclear Facility. If this is the case, site-specific casks can be fully received in the vestibule. Receipt operations 
include receipt quality control inspections, removal of dunnage and up-ending the site-specific casks and moving it to the import-export trolley.

The vestibule gantry crane moves the site-specific cask into room 1001 to the import-export trolley (previously moved into position in room 1001). The trolley is moved to the preparation room (Room 1002) and the lid bolts are removed. The trolley is moved to the main transfer room (Room 1003) and secured in place. If an unloaded site-specific cask is not available from the SNF aging system, a new, empty site-specific cask from the warehouse and non nuclear receipt facility (area 150) is delivered in a horizontal orientation into room 1001 using the site prime mover and site conveyance. The vestibule gantry crane upends the site-specific cask from the conveyance to vertical and moves it to the import-export trolley (previously moved into position in room 1001 and prepared with a pedestal, if necessary). The trolley is moved to the preparation room (Room 1002) and the lid bolts are removed. The trolley is moved to the main transfer room (Room 1003) and secured in place.

For subsequent SNF transfer between transfer bays, the empty site-specific cask is lifted from the import-export trolley to a transfer bay trolley previously prepared with the appropriate pedestal. A docking ring is installed. The transfer trolley with loaded cask is moved into the corresponding fuel transfer bay \#3 (Room 1006) or fuel transfer bay \#1 (Room 1004). The trolley is adjusted into position for subsequent SNF transfer operations. For SNF/HLW canister transfer in Room 1003 the empty site-specific cask is lifted from the import-export trolley, placed into position at the canister transfer station, and secured for canister transfer operations. The lid is remotely removed allowing canister transfer to begin.

Empty Waste Packages: FHF is designed to receive the following empty waste packages:

- 21-PWR

- 12-PWR

- 44-BWR

- 24-BWR
- 5 DHLW/DOE-Long

- 5 DHLW/DOE-Short

- Naval Long

- Naval Short

Waste packages are received at the waste package and receipt facility (area 150), fitted with trunnion collars, and placed into storage with a matched set of inner, middle, and outer lids, and a transfer pedestal. When needed, the waste package with matching lids and pedestal is moved to the FHF using the site prime mover and site conveyance. The waste package is delivered in the vertical position with trunnion collars installed and with the inner lid and protective cap in place. In the entrance vestibule the protective end cap and tie-downs are removed and stored. The pedestal is removed from the conveyance and placed onto the import-export trolley (if required). The waste package is lifted from the conveyance, moved to the import-export trolley, and secured. The outer and middle lids are removed from the conveyance and taken to the WP closure support room (Room 2008) where they are stored until needed.

FHF may operate without the support of the Waste Package Receipt and Non Nuclear Facility. If this is the case, waste packages will be fully received in the vestibule. Receipt operations include receipt quality control inspections, removal of dunnage, installation of trunnion collars and up-ending the waste package and moving it to the import-export trolley. 
The transfer trolley is moved to the main transfer room (Room 1003) and secured in place. For subsequent SNF transfer between transfer bays, the empty waste package is lifted from the import-export trolley to a transfer bay trolley previously prepared with a matching pedestal (if required), and a docking ring installed. The transfer trolley is moved into the corresponding fuel transfer bay \#1 (Room 1004) or fuel transfer bay \#3 (Room 1006) and adjusted into position for subsequent SNF transfer operations. For SNF/HLW canister transfer in room 1003 the empty waste package is lifted from the import-export trolley, placed into position at the canister transfer station, and secured for canister transfer operations. The inner lid is removed allowing transfer operations to proceed.

\section{B.1.2 Waste Transfer}

From Transportation Casks (with non-canistered commercial SNF): Transfer of commercial SNF assemblies is conducted between transfer bays. When an empty waste package (or empty or unloaded site-specific cask) and a loaded cask/site-specific cask are positioned for docking under a docking port, the respective port docking devices are activated. This activation lowers the port docking device to the docking ring and establishes radiological confinement with the floor of the fuel transfer room (Room 2001). The waste package (or empty or unloaded sitespecific cask) inner lid is lifted into a pocket of the docking port plug. The port plug with inner lid is removed and placed in temporary storage in room 2001. Similarly, the docking port plug and the loaded cask/site-specific cask inner lid are removed and placed in temporary storage in Room 2001. SNF waste transfer operations between a loaded cask/site-specific cask and an empty waste package (or empty or unloaded site-specific cask) may begin once the inner lids are removed and stored. When the transfer is completed, the dose rate in the unloaded cask is monitored and the cask interior is visually inspected for remaining items.

Following completion of transfer operations the docking port plug with the waste package inner lid attached is returned to the transfer port. The inner lid is released from the port plug and secured to the waste package. The port docking device is disengaged and the transfer trolley is moved from the transfer bay to the main transfer room (Room 1003). The waste package docking ring is remotely removed and the waste package lifted from the transfer trolley. The transfer trolley is returned to the transfer bay. The WP positioning cell (Room 1013) door is opened and the closure trolley, previously prepared with the appropriate pedestal (if required) is moved into position under the waste package. The waste package is lowered onto the closure cell trolley and moved to room 1013.

In room 1003 the waste package docking ring is swipe surveyed for loose contamination. Any loose contamination is wiped clean to allow re-use of the docking ring. The docking ring is moved to its staging stand within room 1003. If more aggressive decontamination of the docking ring is required than available by FHF means, the docking ring is bagged and placed in storage for decontamination when more aggressive capabilities are established on site.

From Transportation Casks with Canistered SNF/HLW: Transfer of canistered commercial, navy, or DOE SNF/HLW is conducted within the main transfer room (Room 1003). A cask loaded with canistered commercial, navy, or DOE SNF/HLW and an empty waste package (or an 
empty/unloaded site-specific cask) are positioned with inner lids at the canister transfer station on the floor of room 1003. The canister transfer station functions to prevent slap down or unsafe drop of the cask, site-specific cask, waste package or canister during canister transfer. Canistered commercial or DOE SNF/HLW is transferred from the loaded cask to the empty waste package (or an empty/unloaded site-specific cask). Canistered navy SNF is only transferred to an empty waste package. Once the transfer is completed, the dose rate in the cask is monitored and the cask interior is visually inspected for remaining items. Following completion of transfer operations to a waste package, the inner lid is returned to the waste package and the waste package lifted from the floor of the room 1003 to the closure trolley. The trolley is moved into the WP positioning cell (Room 1013).

\section{B.1.3 Waste Package Closure}

Waste package closure operations are performed within the WP positioning cell (Room 1013) using remotely controlled equipment in the WP closure cell (Room 2006) (located directly above room 1013). The inner lid is secured by a spread ring and seal welded, the waste package inner vessel is filled with inert gas and leak tested, the middle and outer lids are welded in place, the welds are non-destructively examined, and residual welding stresses on the outer lid are mitigated. Since periodic adjustments, repairs, and replacements to the closure equipment will be necessary, the equipment will have the capability to be remotely removed from the waste package closure cell and moved into the adjacent WP closure support room (Room 2008) located on the second floor.

\section{B.1.4 Waste Package Load-Out}

Once the loaded waste package is in the WP positioning cell (Room 1013) and the door closed for closure operations, the subsurface waste package transporter (previously loaded with an emplacement pallet from the warehouse and non nuclear receipt facility, (area 150) enters the main transfer room (Room 1003) through the entrance vestibule (Room 1001) and is positioned for waste package loading. The shield door(s) on the transporter are opened, and the bedplate with the waste package emplacement pallet is extended. The emplacement pallet is lifted from the transporter bedplate and placed onto the turntable located within room 1003 and made ready to receive the closed waste package.

When the waste package is welded closed, the waste package transporter and emplacement pallet in position, and the preparation equipment shield door (Room 1002) closed, the door of the WP positioning cell (Room 1013) is opened, and the waste package is returned to the main transfer room (Room 1003). The waste package is moved from the closure trolley to the survey station, remotely inspected for damage and surveyed for contamination. If necessary, limited dry, wipe decontamination is remotely performed to clean the waste package from loose contamination. Following decontamination, the waste package is moved to the tilting fixture within Room 1003 and down-ended to a horizontal position onto the emplacement pallet. The turntable repositions the waste package for remote removal of the trunnion collars by the trunnion collar removal machine. The collars are removed and placed into a holding rack within room 1003.

The emplacement pallet with waste package is lifted from the turntable, moved to the transporter, and lowered into place onto the transporter bedplate. The transporter bedplate is retracted into 
the waste package transporter, the shield door(s) of the transporter are closed, and the waste package transporter is removed from FHF.

\section{B.1.5 Site-Specific Cask Closure}

Once a site-specific cask in a transfer bay is loaded for aging, the docking port plug with the attached shielded, inner lid is returned to the docking port. The inner lid is released from the port plug and returned to the site-specific cask. The port docking device is disengaged and the loaded site-specific cask is moved to the main transfer room (Room 1003). The site-specific cask docking ring is removed, surveyed, decontaminated as necessary, and placed onto a docking ring stand. If more aggressive decontamination of the docking ring is required than available by FHF means, the docking ring is bagged and placed in storage for decontamination when more aggressive capabilities are established onsite. The inner lid is bolted into place and the loaded site-specific cask lifted from the transfer trolley to the import-export trolley located on the FHF central rails. For a site-specific cask loaded at the canister transfer station of room 1003 the inner lid is returned to the site-specific cask and bolted in place and the site-specific cask transferred to the import-export trolley.

The site-specific cask is moved to the preparation room (Room 1002) where external surfaces are swipe surveyed and wipe decontaminated to remove loose contamination, the site-specific cask interior is inerted, and the outer lid installed. The loaded site-specific cask is moved to the room 1001, entrance vestibule.

\section{B.1.6 Site-Specific Cask Load-Out}

When the site-specific cask has been closed and returned to the entrance vestibule (Room 1001), the large gantry crane moves the loaded site-specific cask (in the vertical position) outside of FHF near the exterior door of the entrance vestibule. The gantry crane is withdrawn and the loaded site-specific cask is picked up by the site-specific cask Transporter. The site-specific cask transporter moves the loaded site-specific cask to the SNF/HLW aging system aging pad (Area 17A) for aging.

\section{B.1.7 Transportation Cask/Site-Specific Cask Restoration}

For an unloaded cask/site-specific cask in a transfer bay, the cask/site-specific cask docking port plug with the attached inner lid is retrieved from its storage area in the fuel transfer room (Room 2001) and returned to the port. The inner lid is released and returned to the cask/site-specific cask. The port docking device is disengaged and the transfer trolley with the unloaded cask/sitespecific cask is moved to the main transfer room (Room 1003). The docking ring is removed, surveyed, decontaminated as necessary, and placed onto a docking ring stand (or bagged for later decontamination). The cask/site-specific cask is lifted from the transfer bay trolley, or the floor of room 1003, and moved to the import-export trolley. The import-export trolley is moved to the preparation room (Room 1002). The inner and outer lids are bolted in place.

The unloaded cask/site-specific cask is inspected for external damage, sealing surfaces are inspected, external surfaces are swipe surveyed and decontaminated as necessary, and moved to the entrance vestibule (room 1001). 
For an unloaded cask, an unloaded truck or rail conveyance is moved from the appropriate staging area (Areas 33B and 33A respectively) near the site security gate into Room 1001. The unloaded cask is moved from the cask transfer trolley to the conveyance and down ended in place. Cask tie downs are secured in place, and cask impact limiters, tamper indicating devices and personnel barrier are installed (if required). The unloaded transportation cask is removed from the FHF for return to the national transportation system.

An unloaded site-specific cask is moved just outside room 1001 using the gantry crane. The SNF Aging System transporter picks up the unloaded site-specific cask and returns it to the SNF Aging System aging pad, (Area 17A). 


\section{B.2 Fuel Handling Facility Space Inventory}

The following sections discuss each of the rooms in which the waste processing systems operate, | and the major components accommodated to accomplish the planned process operations. See Figure B-2 for a depiction of Cask/MSC/WP Preparation System functional areas.

\section{B.2.1 Process Systems and Associated Rooms and Equipment}

\section{B.2.1.1 Cask/MSC/WP Preparation System}

The Cask/MSC/WP Preparation System provides: controlled entrance, preparation, and positioning of loaded casks/site-specific casks, empty waste packages, and empty and unloaded site-specific casks for waste transfer; restoration of unloaded casks/site-specific casks for reuse; and controlled exit of unloaded casks for return to the national transportation system and loaded site-specific casks for aging. The Cask/MSC/WP Preparation System operates in the following FHF rooms.

- Room 1001, entrance vestibule

- Room 1002, preparation room

- Room 1003, main transfer room

- Room 1004, 5, and 6, fuel transfer bay \#1, \#2, and \#3 respectively

- Room 2013, main transfer room crane maintenance room

- Room 2014, gas sampling room.

\section{B.2.1.1.1 Room 1001, Entrance Vestibule}

The entrance vestibule (Room 1001) is a single story steel frame structure with steel sheet siding on a concrete foundation. It is located adjacent to the preparation room (Room 1002). Rail tracks connect the two rooms and a shield door separates them. An electric sliding door provides large component entrance to and exit from the FHF. Room 1001 has a 200-ton gantry style crane, the entrance vestibule crane, for handling casks and waste packages with a 30-ton auxiliary hook for removing and re-installing impact limiters, pedestals, and other heavy components. The entrance vestibule crane (200-ton) runs the entire length of the vestibule and has the ability to move out of the vestibule to pick up and deliver site-specific casks.

Space is provided for staging the appropriate set of lifting yokes, stands, pedestals, tie downs, impact limiters, personnel barriers, and a cask tilting machine. A complete set of lifting and handling devices will be stored outside of FHF and staged in to the entrance vestibule as needed.

The vestibule allows the cask/site-specific cask or waste package conveyance to enter the facility without exposing the interior processing areas to the external environment. The entire conveyance including a site prime mover is moved into the building and the door closed. The vestibule is designed to accommodate a rail car (not including the prime mover) up to 72' long by 10’ 8”’ wide (BSC 2004 [DIRS 101648] Fig. 8-8).

The entrance vestibule is sized to stage at least one set of the necessary yokes, tie-downs, impact limiters, personnel barrier etc. to handle either a cask, site-specific cask, or waste package. Additional storage will be provided elsewhere, outside of FHF, for such equipment to handle the 
variety of casks and waste packages. This equipment will be brought to FHF on demand. For transfers conducted between transfer bays, two matching pedestals for each cask, site-specific cask, and waste package are required, one for the import-export trolley and one for the transfer bay trolley. Once a waste package is moved from the import-export trolley to the transfer bay trolley, the pedestal on the import-export trolley can be moved to the closure trolley to support closure operations.

Major components required for cask, site-specific cask, and waste package preparation in room 1001 are:

- Rail tracks

- Preparation equipment shield door

- Vestibule entrance door

- Gantry crane (200/30-ton)

- Site prime mover

- Site conveyance

- Mobile elevated platform

- Transportation cask, or site-specific cask, or waste package

- Transportation cask, cask yoke, yoke stand, cask tie downs, personnel barrier, and cask impact limiters (one set); matching pedestal (two sets)

- Site-specific cask, site-specific cask yoke, and yoke stand (one set); and matching pedestal (two sets)

- Waste package, matching lids, yoke, and yoke stand (one set); and matching pedestal (two sets)

- Hi Star tilting frame

- Yokes and yoke stands

- Import-export trolley

- Health physics station (smear and radiation survey equipment, wipes)

- Cask preparation tools and tool stand.

\section{B.2.1.1.2 Room 1002, Preparation Room}

The preparation room (Room 1002) is a concrete cell located between the entrance vestibule (Room 1001) and the main transfer room (Room 1003). Rail tracks connect the three rooms and shield doors separate them. The main transfer room crane maintenance room (Room 2013) is located directly overhead of room 1002.

A complete set of lifting and handling devices will be stored outside of FHF and staged in to the preparation room as needed.

When a cask or a site-specific cask is brought into Room 1002 from Room 1001, a mobile elevated platform can be moved in place next to it for personnel access to the outer and inner lids. Cask/site-specific cask preparations are conducted primarily from Room 2013 (described below) with assistance from personnel on the platform. These include venting and gas sampling of the cask interior. When cask/site-specific cask preparations are completed, the mobile platform is moved away from the trolley to a staging position within room 1002 and the trolley is moved into the main transfer room (Room 1003). 
When an unloaded cask, unloaded site-specific cask, or loaded site-specific cask is returned from room 1003 to room 1002, the operational steps performed within room 1002 are reversed. Major components required for cask, site-specific cask, and waste package preparation in room 1002 are:

- Rail tracks

- Main transfer equipment shield door

- Personnel access shield door

- Hatch to room 2013

- Import-export trolley with pedestal and cask/site-specific cask

- Mobile elevating platform.

\section{B.2.1.1.3 Room 1003, Main Transfer Room}

The main transfer room (Room 1003) is a two-story concrete shielded cell located between the preparation room (Room 1002) and fuel transfer bays 1, 2, and 3 (Rooms 1004, 1005, and 1006 respectively). Located adjacent to room 1003 is the WP positioning cell (Room 1013) and the main transfer operating gallery (Room 1015). Rail tracks connect rooms 1002 with room 1003. Trolley tracks connect room 1003 with the three transfer bays. Shield doors separate rooms 1002, 1004, 1005, 1006, and 1013 from room 1003. At the second floor, room 1003 is located between the main transfer room crane maintenance room (Room 2013) and the fuel transfer room (Room 2001). A 200-ton overhead bridge crane (main transfer bridge crane) with 30-ton auxiliary hook runs the length of room 1003.

For uncanistered SNF transfer involving a loaded cask between the transfer bays, a matching | cask pedestal is brought into room 1003. The 30-ton auxiliary hook is used to place the pedestal onto the transfer trolley of the fuel transfer bay \#2 (Room 1005). A loaded cask is brought into room 1003 with the outer lid, sample port access cover, and inner lid bolts removed and a lid lifting fixture attached to the inner lid. Using the main transfer bridge crane, the loaded cask is lifted from the import-export trolley to the transfer bay trolley. A mobile, elevated platform is moved into place next to the loaded cask for personnel to install a docking ring. The 30-ton auxiliary hook moves a docking ring from the main transfer room crane maintenance room (Room 2013) to room 1003 for installation on the cask. The transfer trolley is moved into room 1005 and adjusted into position for subsequent SNF/HLW transfer operations.

Space is provided for staging the appropriate set of lifting yokes, stands, A complete set of | lifting and handling devices will be stored outside of FHF and staged in to the main transfer room as needed.

Major components required for cask, site-specific cask, and waste package preparation in room 1003 are:

- Rail tracks

- Trolley tracks (four sets)

- Shield doors (five)

- Personnel access shield doors (two)

- Main transfer room crane (200/30-ton)

- Import-export trolley 
- Transfer bay trolleys (three)

- Closure trolley

- Transportation cask

- Site-specific cask

- Waste package

- Mobile elevated platform

- Canister transfer station.

\section{B.2.1.1.4 Room 1004, 1005, and 1006: Fuel Transfer Bay \#1, 2, and 3 respectively}

The fuel transfer bays (Rooms 1004, 1005, and 1006 respectively) are single story concrete cells located between the main transfer room (Room 1003) and the remote HEPA filter room (Room 1007). Located adjacent to room 1004 is the WP gas inerting room (Room 1009). Trolley tracks connect the three transfer bays with room 1003 and shield doors separate them. Trolley tracks connect room 1005 with room 1007 through an opening between the two rooms for removal of used HEPA filters.

Major components required for cask, site-specific cask, and waste package preparation in rooms 1004, 1005, and 1006 are:

- Trolley tracks

- Transfer bay trolley and waste package (Room 1004)

- Transfer bay trolley and cask (Room 1005)

- Transfer bay trolley and site-specific cask (Room 1006)

\section{B.2.1.1.5 Room 2013, Main Transfer Room Crane Maintenance Room}

The main transfer room crane maintenance room (Room 2013) is located adjacent to the main transfer room (Room 1003) and near the gas sampling room (Room 2014). A shield door separates room 2013 from room 1003 . Room 2013 is also located directly over the preparation room (Room 1002). A floor hatch provides access from room 2013 into casks or site-specific casks positioned in room 1002. The 200-ton overhead bridge crane and 30-ton auxiliary hook run the length of room 2013.

When a loaded cask is moved from the entrance vestibule (Room 1001) to room 1002 and is positioned under the hatch, the cask outer lid (where applicable) and sample port access cover are removed and stored using the auxiliary overhead bridge crane as needed, gas samples are taken and analyzed, and inner lid bolts are removed and stored. For subsequent uncanistered SNF transfer between transfer bays, a lifting fixture is attached to the inner lid. The trolley is then moved into the main transfer room (Room 1003). A loaded site-specific cask undergoes the same preparation and is moved to room 1003 . When an empty or unloaded site-specific cask is moved from room 1001 to room 1002, the lid bolts are removed, a lifting fixture is attached to the inner lid, and the trolley is moved to Room 1003.

Empty waste packages receive no preparation in Room 1002 (the inner lid lifting fixture is integral with the inner lid). Docking rings are staged in Room 2013 until needed for installation onto casks, site-specific casks, or waste packages (in Room 1003). 
When an unloaded cask, unloaded site-specific cask, or loaded site-specific cask is returned from room 1003 to room 1002 for restoration operations, the operational steps performed within room 2013 are reversed. However, no unloaded cask or unloaded site-specific cask gas sampling and analysis is performed. A loaded site-specific cask is inerted.

Major components required for cask, site-specific cask, and waste package preparation in room 2013 are:

- Shield door

- Cask/site-specific cask preparation tools and tool stand

- Hatch cover

- Outer lid lifting fixture

- Outer cask/site-specific cask lid (three sets desired, one set required)

- Cask/site-specific cask sample port access cover (three sets desired, one set required)

- Cask/site-specific cask inner lid bolts (three sets desired, one set required)

- Cask/site-specific cask inner lid lifting fixture (three sets desired, one set required)

Docking rings (three sets desired, one set required)

- Gas sampling and analysis equipment

- Inerting equipment

- Auxiliary hook (30-ton).

\section{B.2.1.1.6 Room 2014, Gas Sampling Room}

The gas sampling room (Room 2014) is located adjacent to the main transfer room crane maintenance room (Room 2013) and the waste package closure support room (Room 2008). This room provides space and layout for gas sampling and analysis equipment utilized during cask/site-specific cask preparation operations.

\section{B.2.1.2 SNF/HLW Transfer System}

The SNF/HLW waste transfer system provides: transfers of uncanistered SNF from a loaded cask/site-specific cask positioned in a transfer bay to an empty waste package/site-specific cask positioned in a transfer bay; transfers of canistered SNF/HLW from a loaded cask/site-specific cask positioned at the canister transfer stand to an empty waste package/site-specific cask positioned at the canister transfer stand; removal and restoration of docking rings for re-use; positioning of loaded waste packages for closure operations; load out of closed waste packages; and selected site-specific cask closure and loadout operations. The SNF/HLW transfer system processing rooms are:

- Room 1003, main transfer room

- Room 1013, WP positioning cell

- Room 1015, main transfer operating gallery

- Room 2001, fuel transfer room

- Room 2002, fuel transfer operating gallery

- Room 2013, main transfer room crane maintenance room 


\section{B.2.1.2.1 Room 1003, Main Transfer Room}

The emplacement pallet with waste package is lifted from the turntable, using a special emplacement pallet lifting yoke, moved to the transporter, and lowered into place onto the transporter bedplate. The transporter bedplate is retracted into the waste package transporter, the shield door(s) of the transporter are closed, and the waste package transporter is removed from FHF.

When a loaded site-specific cask is returned from a transfer bay to room 1003, or when canister transfer to a site-specific cask within is completed, a mobile, elevated platform is moved into place next to the loaded site-specific cask for personnel to detach the docking ring or protective collar. The docking ring collar is removed, using the main transfer room crane (30-ton auxiliary hook), swipe surveyed and decontaminated as necessary, and returned to the staging stand within Room 2013. If necessary the docking rings are bagged and moved to storage pending more aggressive decontamination capability. The inner lid is bolted into place. The mobile, elevated platform is removed and the 200-ton crane lifts the loaded site-specific cask from the transfer bay trolley or the canister transfer stand to the import export trolley, and returns the trolley with site-specific cask to preparation room (Room 1002) for the site-specific cask closure operations.

Major components supporting SNF/HLW transfer system operations in room 1003 are:

- Rail tracks

- Trolley tracks (four sets)

- Shield doors (five)

- Main transfer room crane (200/30-ton)

- Import-export trolley with pedestal

- Transfer bay trolley (three)

- Closure trolley

- Transportation cask

- Site-specific cask

- Waste package

- Mobile elevated platform

- Canister transfer station

- Trunnion collar removal machine

- Trunnion collar storage rack

- Waste package tilting machine

- Waste package turntable

- Lifting yokes and stands

- Waste package pallet lifting yoke

- Swab and decon power manipulator.

During waste package load out operations, the preparation room (Room 1002) and the main transfer room (Room 1003) provide space for the waste package transporter.

When the waste package transporter is parked, the exterior shield door of room 1002 is closed, the shield door(s) on the transporter are opened, and the bedplate with the waste package 
emplacement pallet extended. The emplacement pallet is lifted from the transporter bedplate using the main transfer room crane (200-ton) and placed on the WP turntable.

Following waste package closure operations, the door of the WP positioning cell (Room 1013) is opened and the SNF/HLW transfer system returns the waste package to the main transfer room (Room 1003). All loaded waste package handling operations in room 1003 are performed remotely using the main transfer room crane (200-ton) and various staged equipment. The waste package is moved from the closure trolley to the survey station, remotely inspected for damage and surveyed for contamination. The facility design includes the capability to perform remote visual inspection via shielded windows and close circuit camera of a waste package prior to loading onto a waste package transporter. If necessary, limited dry, wipe decontamination is remotely performed to clean the waste package from loose contamination. Following decontamination, the waste package is moved to the waste package tilting machine within room 1003 and down-ended to a horizontal position onto the emplacement pallet. The turntable repositions the waste package for remote removal of the trunnion collars by the trunnion collar removal machine. The collars are removed and placed into a holding rack within room 1003.

The emplacement pallet with waste package is lifted from the turntable, moved to the transporter, and lowered into place onto the transporter bedplate. At this point, the emplacement and retreival system then takes over from the HLW/SNF transfer sytem. The transporter bedplate is retracted into the waste package transporter, the shield door(s) of the transporter are closed, and the waste package transporter is removed from FHF.

Major emplacement and retrieval system components requiring space accommodation in rooms 1001, 1002, and 1003 are:

- Subsurface waste package transporter

- Subsurface locomotive

- Waste package pallet.

\section{B.2.1.2.2 Room 1013, WP Positioning Cell}

The WP positioning cell (Room 1013) is adjacent to the main transfer room (Room 1003). A sliding shield door separates these two rooms, trolley tracks connect them. This trolley track has a dedicated trolley (closure transfer trolley). Above room 1013, is the WP closure cell (Room 2006).

Room 1013 provides space and layout for a loaded waste package to be positioned under the closure equipment of the overhead closure room. The SNF/HLW transfer system moves the waste package from room 1003 to room 1013 and secures it within the required tolerances in both the lateral and vertical directions. The waste package closure system assumes control, and performs the necessary waste package closure operations. When closure operations are completed, the SNF/HLW transfer system moves the sealed waste package back into Room 1003.

Major components requiring space accommodation in room 1013 are:

- Trolley tracks 
- Closure transfer trolley

- Sliding shield door

Waste package

\section{B.2.1.2.3 Room 1015, Main Transfer Operating Gallery}

The main transfer operating gallery (Room 1015) is located adjacent to the main transfer room (Room 1003) and directly below WP closure support room (Room 2008). Access from room 1015 to room 1003 is provided through two sets of master slave manipulators and a remote power manipulator. This room is designed for occupancy by operating personnel monitoring and controlling transfer operations. The remote power manipulator is used to swipe survey the closed waste package for loose contamination, and to perform light decontamination as necessary. Wall penetrations with posting ports are provided to pass swipes between rooms 1015 and 1003. The master slave manipulators are used to support waste package loadout operations. Major components requiring accommodation in room 1015 are:

- Master slave manipulator (two sets)

- Shield windows (three)

- Table/desk (three)

- Wall penetrations with posting ports.

\section{B.2.1.2.4 Room 2001, Fuel Transfer Room}

The fuel transfer room (Room 2001) is located directly overhead the three transfer bays and adjacent to and overhead of the fuel transfer operating gallery (Room 2002). A 1.5-ton capacity fuel transfer machine (FTM) runs north-south and covers the entire length of room 2001, traversing all three transfer bays. The fuel transfer maintenance crane (30 ton) located above the FTM runs east-west and covers the entire length and width of room 2001. Remote access from room 2002 into room 2001 is provided via three sets of master slave manipulators.

Major components requiring accommodation in room 2002 are:

- Fuel Transfer Machine (1.5-ton)

- Fuel Transfer Maintenance Crane (30-ton)

- Master slave manipulators (three sets)

- Port hatch assemblies (three)

- SNF assembly grapples

- Cask dose rate monitoring equipment

- Cask interior visual inspection equipment

- Power manipulator

- Posting Port

- Fuel transfer vacuum system 


\section{B.2.1.2.5 Room 2002, Fuel Transfer Operating Gallery}

The fuel transfer operating gallery (Room 2002) is located adjacent to the fuel transfer room (Room 2001). Room 2002 provides three master slave manipulators along the wall separating the two rooms to assist with SNF/HLW transfer operations in room 2001. Major components requiring accommodation in room 2002 are:

- Master slave manipulator (three sets)

- Shield windows (three)

- Table/desk (three)

- Wall penetrations

- Posting port with glovebox.

\section{B.2.1.3 WP Closure System}

The WP closure system provides safe, controlled, accurate, and consistent closure operations of waste packages. Waste package closure begins once SNF/HLW transfer system has positioned the waste package in the WP positioning cell (Room 1013). The WP closure system assumes control and conducts closure operations. Waste package closure ends once all closure operations are completed and control is transferred to the SNF/HLW transfer system. The SNF/HLW transfer system removes the sealed waste package from the room 1013 for the subsequent processing steps. The WP closure system requires space and layout for remotely operated equipment used to weld the waste package lids to the waste package, inert the waste package, mitigate weld stresses (outer lid only), and perform non-destructive examination of the closure welds. The major WP closure system processing rooms are:

- Room 1013, WP positioning cell (See SNF/HLW Transfer System, Section B.2.1.2.2)

- Room 1016, maintenance room

- Room 2005, WP closure operating gallery

- Room 2006, WP closure cell

- Room 2008, WP closure support room

- Room 2010, WP closure maintenance room

- Room 3001, WP closure equipment room.

\section{B.2.1.3.1 Room 1016, Maintenance Room}

The maintenance room (Room 1016) is located adjacent to the WP positioning cell (Room 1013), the main transfer operating gallery (Room 1015), and the freight elevator lobby \#1 (Room 1025). A roll up door provides access from room 1016 to room 1025 . Room 1016 provides space for maintenance of master slave manipulators, general maintenance activities, tools, and equipment.

\section{B.2.1.3.2 Room 2005, WP Closure Operating Gallery}

The WP closure operating gallery (Room 2005) is located adjacent to the WP closure cell (Room 2006) and the corridor (Room 2004). Room 2005 provides two master slave manipulators along the wall separating the two rooms and control consoles to assist with closure operations in room 2006. Major components requiring accommodation in room 2002 are: 
- Master slave manipulator

- Shield windows

- Control consoles

- Wall penetrations.

\section{B.2.1.3.3 Room 2006, WP Closure Cell}

The WP closure cell (Room 2006) is a concrete shielded "hot" cell located directly over the WP positioning cell (Room 1013) and the WP closure trolley room (Room 1014), and adjacent to WP closure maintenance room ( Room 2010). A 15-ton WP closure cell overhead bridge crane traverses north-south and covers the length of rooms 2006 and 2010. Room 2006 provides space for two robotic arms that allow the various welding and inspection tools to be placed in position at the top of the waste package. A second overhead bridge crane, the remote handling crane (3ton), with a separate manipulator arm for finer movement tasks, is also provided. The remote handling crane travels the full width and length of the closure room to augment the 15-ton WP closure cell overhead bridge crane

Closure operations are performed within the boundaries of the closure room using remotely operated equipment. Periodic adjustments, repairs, and replacements to this equipment will be necessary. To facilitate repairs this equipment is designed to be remotely disengaged and moved into Room 2010 or the WP closure support room (Room 2008). Major components requiring space accommodation in the WP closure cell are:

- WP closure robotic arms

- WP closure manipulator arm

- WP closure cell crane (15-ton)

- Remote handling crane (3-ton)

- Spread ring

- Middle lid

- Outer lid

- Inerting equipment

- Welding equipment

- Non-destructive examination equipment

- Weld stress mitigation equipment.

\section{B.2.1.3.4 Room 2008, WP Closure Support Room}

The WP closure support room (Room 2008)is located adjacent to the WP closure cell (Room 2006) and the Freight Elevator Lobby (Room 2025), and directly over the maintenance room (Room 1016). The room provides space and layout for a large, shielded glove box, closure support crane (15-ton), and tooling necessary for the maintenance of waste package closure equipment. Room 2008 provides an equipment access hatch to the first floor and a large equipment door providing access to the nearby freight elevator. Large equipment may be brought into and out of room 2008 through the equipment floor hatch from room 1016 or via the large equipment door and freight elevator. Equipment can be transferred between room 2008 and room 2006 via the shielded glove box. Room 2008 is designed to allow for continuous 
occupancy by personnel supporting the closure cell operations.. Major components requiring space accommodation in the WP closure support room are:

- Large shielded glove box

- Closure support crane (15-ton)

- Large equipment door

- Floor equipment hatch

- Maintenance tooling.

\section{B.2.1.3.5 Room 2010, WP Closure Maintenance Room}

The WP closure maintenance room (Room 2010) is located adjacent to the WP closure cell (Room 2006) and the WP closure support room (Room 2008). Room 2010 provides equipment access to room 2006 and personnel access to room 2008.

Room 2010 provides storage space for items necessary to support waste package closure operations such as lids, consumables, and tooling. A sliding shield door separates room 2010 from room 2006. Room 2010 provides space for maintenance on cranes and leak test tools. .

\section{B.2.1.3.6 Room 3001, WP Closure Equipment Room}

The WP closure equipment room (Room 3001) is located directly above the WP closure support room (Room 2008) and the WP closure cell (Room 2006). Room 3001 provides access to each room through individual floor hatches. The hatch over room 2006 is shielded. Room 3001 provides a closure maintenance crane (15-ton) to assist with the repair and removal of waste package closure equipment, and space allocation for stress mitigation equipment.

\section{B.2.1.4 SNF Aging System}

The SNF aging system operates within the FHF in that site-specific casks are routed through the facility for processing. Details of this system are presented in SNF aging system design documentation. New, empty site-specific casks are received from the warehouse and non nuclear receipt facility (Area 230), prepared for waste transfer operations, and docked. Re-usable, unloaded site-specific casks are transferred to the FHF when needed using the aging system transporter.

Once SNF and HLW transfer operations are completed, the loaded site-specific cask is closed and picked up by the aging system transporter for transfer to an SNF aging pad for aging. Loaded site-specific casks with aged fuel are received from an SNF aging pad, prepared for waste transfer operations, and docked. Once SNF and HLW transfer operations are completed, the unloaded site-specific cask is surveyed, decontaminated if necessary, and removed from the FHF to the SNF aging for later reuse. The rooms in which site-specific casks are processed are discussed in Section B.2.1.1, Cask/MSC/WP Preparation System, and Section B.2.1.2, | SNF/HLW transfer system.

\section{B.2.2 INFRASTRUCTURE SYSTEMS}




\section{B.2.2.1 Digital Control and Management Information System}

The central control center facility (Area 240) will be located in a stand alone facility. The control center includes the central control room, communications and the engineering configuration room. The FHF will be monitored from the central control center facility, select systems controlled, and other systems maintained on a supervisory level. The central control center facility houses human machine interface and other support. No space will be provided in FHF for these control center functions. The DCMIS will have input/output cabinets physically located within FHF. Details of this system are presented in digital control and management information system design documentation. Space for local control panels/consoles will be provided in room 1015 and room 2002 to remotely operate the equipment in high radiation areas.

\section{B.2.2.2 Environmental/Meteorological Monitoring System}

Meteorological monitoring instruments are mounted on the repository meteorological towers. These towers are strategically located throughout the Site. The meteorological instruments interface with a transceiver mounted on an instrument rack in the central control center facility. Operators gather meteorological information from the transceiver.

Environmental monitoring is aligned with seismic activities. Motion analyzers are located in a specific manner by qualified seismic specialists. These motion analyzers interface with an accelerometer mounted on an instrument rack in the control room complex. The instrument rack is located near the digital control and management information system. Details of this system are presented in environmental/meteorological monitoring system design documentation.

\section{B.2.2.3 Radiation/Radiological Monitoring System}

Radiation and radiological monitoring instruments are placed in specific locations throughout the FHF, as needed for monitoring functions. Details of this system are presented in radiation/radiological monitoring system design documentation.

\section{B.2.2.4 Low-Level Radioactive Waste Generating System}

The low-level radioactive waste generating system includes several subsystems that support cask and site-specific cask receipt, preparation, and restoration, as well as waste package closure and loadout. The cask cavity gas sampling system detects the presence of failed fuel before a transportation cask is opened. The cask inerting system provides for inerting with helium of transportation casks and site-specific casks. The waste package inerting system provides for inerting with helium of waste packages. The surveying of external surfaces of waste packages for removable radiological contamination system ensures each waste package is surveyed for removable radiological surface contamination. The function of the decontamination of external surfaces of waste package system is to ensure decontamination of external surfaces of waste packages. Details of these systems are presented in the low-level waste generating systems system design documentation.

\section{B.2.2.5 Low Level Radioactive Waste Management System}


The low-level radioactive waste management system collects, processes, and disposes of lowlevel radioactive waste streams generated within FHF during processing of HLW and SNF. Details of the low-level radioactive waste management system are presented in low level radioactive waste management system design documentation.

\section{B.2.2.6 Non-Radiological Waste Management System}

The non-radiological waste management system collects, handles, and disposes of all nonradioactive, hazardous and non hazardous waste generated within FHF during processing of HLW and SNF. Details of this system are presented in non-radiological waste management system design documentation.

\section{B.2.2.7 Electrical Power System}

The electrical power system for the FHF is comprised of 480 VAC load centers and motor control centers (MCCs) that are housed in the FHF electrical room. The load centers are supplied from a $4,160 \mathrm{~V}$ to $480 \mathrm{VAC}$ ventilated dry-type transformer that is part of the load center enclosure and is fed from the site electrical distribution system by way of an underground electrical duct bank system. The electrical duct bank system interfaces with the FHF. The load centers are capable of supplying normal loads and distribute down to the MCCs for further distribution to smaller loads. The emergency MCCs are supplied from emergency $4160 \mathrm{~V}$ to 480 V dry type transformer that is part of the MCC enclosure. The emergency MCCs are capable of supplying emergency power to ensure power remains available to ITS loads. The FHF also contains a number of low voltage components (e.g., uninterruptible power supply and small power transformers and panels) powered from the $480 \mathrm{VAC}$ motor control centers. The motor control centers are powered from the 480 VAC load centers. Details of this system are presented in electrical power system design documentation.

\section{B.2.2.8 Electrical Support System}

The electrical support system for the FHF includes a number of subsystems such as the lighting system, grounding system, lightning protection system, heat tracing system, raceway system, and cathodic protection system. These systems include lighting fixtures, cable trays, conduits, and cables. Details of this system are presented in electrical support system design documentation.

\section{B.2.2.9 Plant Services System}

The plant services system provides water (raw, potable, deionized, and cooling tower water), fuel oils (diesel and gasoline), compressed air (breathing, instrument, and general purpose air), and service gases (nitrogen, argon, helium, and argon/helium blend) to surface facilities as required. Fuel oils are not provided to FHF. Details of this system are presented in plant services system design documentation

\section{B.2.2.10 Communications System}

The communications system central area in the FHF is located in the backup central communications room (Room 2036) and is primarily comprised of communications racks that 
provide redundancy the site communications system. Details of this system are presented in communications system design documentation.

\section{B.2.2.11 Fire Protection System}

The fire protection system provides fire water, fire suppression, fire detection, fire alarm, explosion protection, and fire barriers within FHF. Details of this system are presented in fire protection system design documentation.

\section{B.2.2.12 Safeguards and Security System}

The safeguards and security system is located in the safeguards/security room (Room 1010) of the FHF. The room accommodates security personnel with desks, computers, and a console with monitoring and alarming equipment. In addition, the room is equipped with a vault where potentially sensitive equipment and documentation may be kept. Details of this system are presented in safeguards and security system design documentation.

\section{B.2.2.13 HVAC Plant Heating and Cooling System}

The HVAC plant heating and cooling system, in conjunction with the surface nuclear and industrial HVAC systems, provides proper design conditions for workers and equipment in the surface facilities. The HVAC plant heating and cooling system provides chilled water from centralized chillers to the cooling coils in the air handling units (of the surface nuclear and industrial HVAC systems) located in the FHF. The HVAC plant heating and cooling system also provides hot water from centralized boilers to the preheat heating coils in the air handling units and duct mounted reheat coils (of the surface nuclear and industrial systems) located in the FHF. The HVAC plant heating and cooling system within the FHF consists primarily of distribution piping. Details of this system are presented in HVAC plant heating and cooling system design documentation.

\section{B.2.2.14 Surface Nuclear HVAC System}

The surface nuclear HVAC system, consisting of the primary confinement HVAC subsystem and secondary and tertiary confinement HVAC subsystem, serves the potentially contaminated zones (i.e., the primary, secondary, and tertiary confinement zones) of the FHF.

The surface nuclear HVAC system provides conditioned air for cooling, heating, and ventilation to ensure the air quality standard required for safety, health, and comfort of occupational workers. The system also maintains the environmental conditions suitable for the proper performance of the equipment and components which includes cooling of the waste packages/casks/site-specific casks in the transfer bays (Rooms 1004, 1005, 1006).

The system provides continuous airflow and controlled differential pressure to limit crosscontamination between contaminated and uncontaminated areas by directing air from areas of lesser potential for airborne contaminants to areas of greater potential for airborne contaminants and finally to areas that are normally contaminated. In addition, the system limits the release of airborne contaminants from the facility to the outside atmosphere for the protection of the environment, workers, and the public. 
The surface nuclear HVAC system consists of components dedicated to supplying air to the facility or exhausting air from the facility. The supply subsystem components consist of air handling units (with filters, heating coils, and cooling coils), supply fans, outside air intakes, supply air distribution ductwork, reheat coils, pressure control dampers, air balancing devices, and isolation dampers. The exhaust subsystem components consist of exhaust air cleaning units (with prefilters, demisters, HEPA filters, and charcoal adsorbers, if required), exhaust fans, pressure control dampers, isolation dampers, air-balancing devices, ductwork, and a discharge air stack with stack monitoring capability. Contaminated air from the confinement zones is filtered through HEPA filters to remove radioactive airborne contamination prior to exhausting through the ventilation exhaust stack.

The design of FHF provides for the remote change out of HEPA filters serving as prefilters for primary confinement HEPA filter exhaust subsystem. The remote HEPA filter room (Room 1023) is a single story concrete cell adjacent to the fuel transfer bays and the electrical room (Room 1008). Trolley tracks connect room 1005 with room 1023 through an opening between the two rooms. Room 1023 is used to position the filter export trolley with shielded HEPA filter boxes. Room 1007 provides space for functioning HEPA filter trains. A (10-ton) filter handling machine provides the means to remotely remove used HEPA filters from service and place them into the shielded boxes. The opening between rooms 1005 and 1023 provides the means to remove used HEPA filters from FHF for disposal and to install new HEPA filters without worker exposure to potentially high radiation and contamination levels.

When filter replacement is required the filter export trolley is positioned in the main transfer room (Room 1003). At least two HEPA filter shield boxes, each containing a clean remotely replaceable HEPA filter, are moved from the entrance vestibule (Room 1001) through the preparation room (Room 1002) into the main transfer room (Room 1003) and placed on the filter export trolley. The shield boxes are prepared for remote operations that are necessary during transfer of the contaminated HEPA filters. After preparation of the shield boxes the fuel transfer bay 2 (Room 1005) shield door is opened and the filter export trolley is moved to the east end of fuel transfer bay 2 (Room 1005) and positioned under the docking ports to filter transfer. Confinement isolation devices are then connected to the shield boxes. This allows confinement of the shield box internals to the remote HEPA filter room (Room 1007) during transfer of contaminated HEPA filters.

The standby filter bank is activated before shutting down the unit designated for filter replacement. The standby filter plenum is activated by removing the isolation gate port covers, upstream side first, removing the isolation gates and replacing the isolation gate port covers. The filter bank that requires filter replacement is then deactivated by removing the isolation gate port covers, upstream side first, installing the isolation gates and replacing the isolation gate port covers.

After confinement is established between the shield box and remote HEPA filter room (Room1007) the filter handling machine lifts the transfer hatch covers and the shield box lids and places them in the remote HEPA filter room (Room 1007). The clean HEPA filters are removed from the shield boxes and placed in the remote HEPA filter room. The filter handling machine removes the two filter port covers over the used HEPA filters and places them in the remote HEPA filter room (Room 1007). The used HEPA filters are removed from the filter plenum, one at a time, and placed into the shield boxes one per box. The filter handling machine retrieves the 
clean HEPA filters, places them into the empty slots, and replaces the filter port covers. The filter handling machine then replaces the shield box lids and the transfer hatch covers and the confinement isolation device is separated from the shielded boxes.

After the isolation device is separated from the shield box and the transfer hatch covers are in place, the shield door between the main transfer room and Fuel Transfer Bay 2 is opened. The filter export trolley is moved into position in the main transfer cell (Room 1003) for exit preparation and the shield door is closed. Personnel can now enter the main transfer cell (Room 1003), bolt the shield box

Major components required by the surface nuclear HVAC system in room 1007 are:

- HEPA filters

- Trolley tracks

- Filter export trolley with shielded HEPA filter boxes for used HEPA filters

- HEPA filter handling machine (10-ton).

\section{B.2.2.15 Surface Industrial HVAC System}

The surface industrial HVAC system serves the clean, non confinement zones of the FHF not served by the surface nuclear HVAC system. The surface industrial HVAC system includes the electrical equipment room HVAC subsystem and the support rooms and offices HVAC subsystem. The subsystems are provided with a recirculation HVAC system.

The surface industrial HVAC system provides conditioned air for cooling, heating, and ventilation to ensure the minimum air quality standard required for the safety, health, and comfort of workers and the proper performance of equipment and components.

The system provides pressure differentials that are maintained slightly positive (relative to ambient) to minimize infiltration of unconditioned air and dust during system operation. The surface industrial HVAC system also provides positive pressure differentials relative to the ventilation contamination confinement zones to preclude cross-contamination from those areas.

The surface industrial HVAC system configuration consists of outside air intakes, supply air handling units (with integral air filters, heating coils, cooling coils, humidifiers if required, and supply fans), exhaust fans, return air in the recirculating systems, air distribution ductwork, and accessories including balancing, control, and instrument devices. 


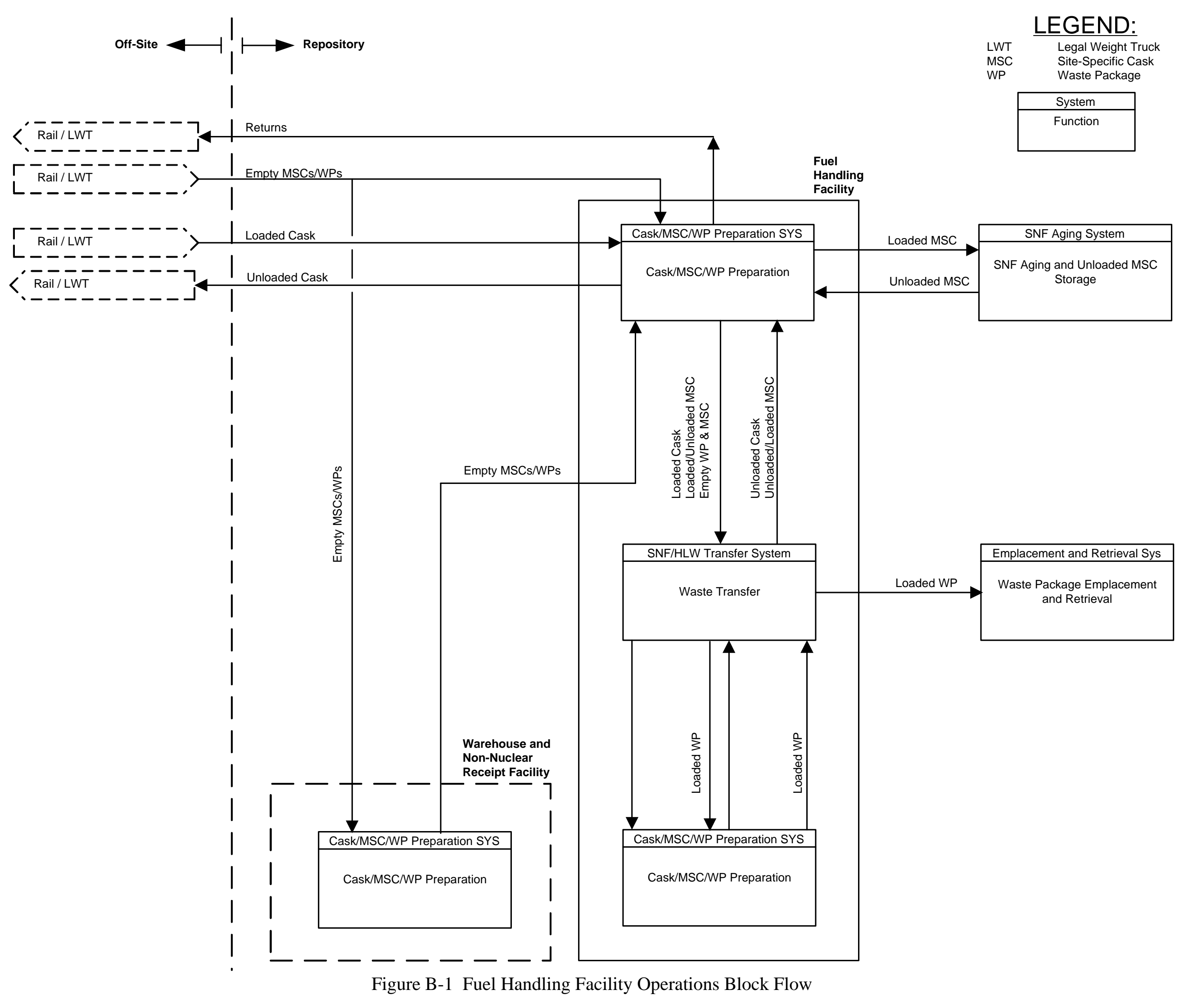




\section{MATERIAL FLOW PATH}

TRANSPORTATION CASK OPERATIONS

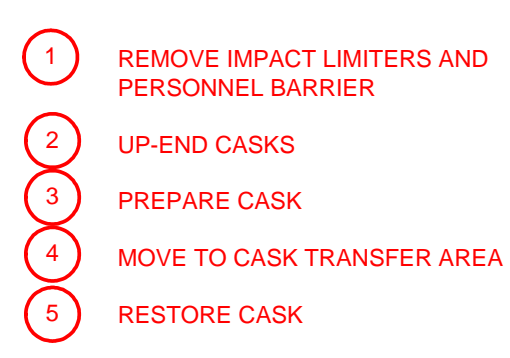

SITE-SPECIFIC CASK OPERATIONS

1 RECEIVE SITE SPECIFIC CASK

2 UP.END SITE SPECIFIC CASK

3 PREPARE SITE SPECIFIC CAS

4 MOVE SITE SPECIFIC CASK TO

5 RESTORE SITE SPECIFIC CASK

6 POSITION SITE SPECIFIC CASK FOR

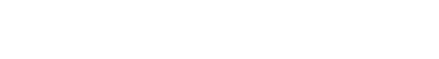

WASTE PACKAGE OPERATIONS
(1) RECEIVE EMPTY WASTE PACKAGE
(2) PREPARE WASTE PACKAGE
(3) MOVE TO TRANSFER AREA
(4) MOVE WASTE PACKAGE TO
(5) MOVE WASTE PACKAGE TO CLOSURE
(6) WASTE PACKAgE LOADOUT

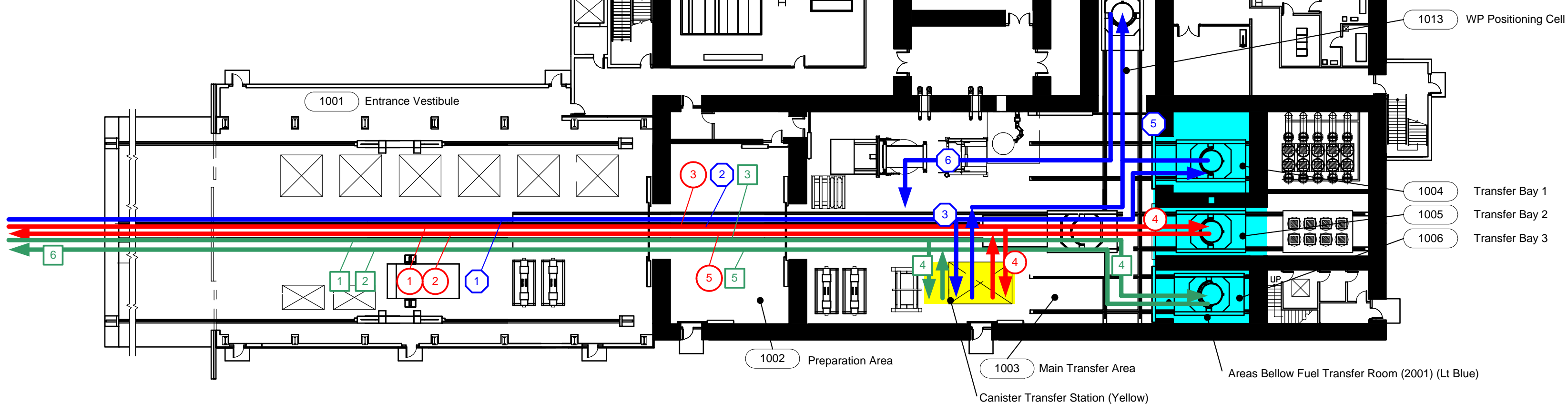

FUEL HANDLING FACILITY

Figure B-2 Cask/MSC/WP Preparation System Functional Areas 
Maximum Inventory of Casks and Waste Packages within the Fuel Handling Facility

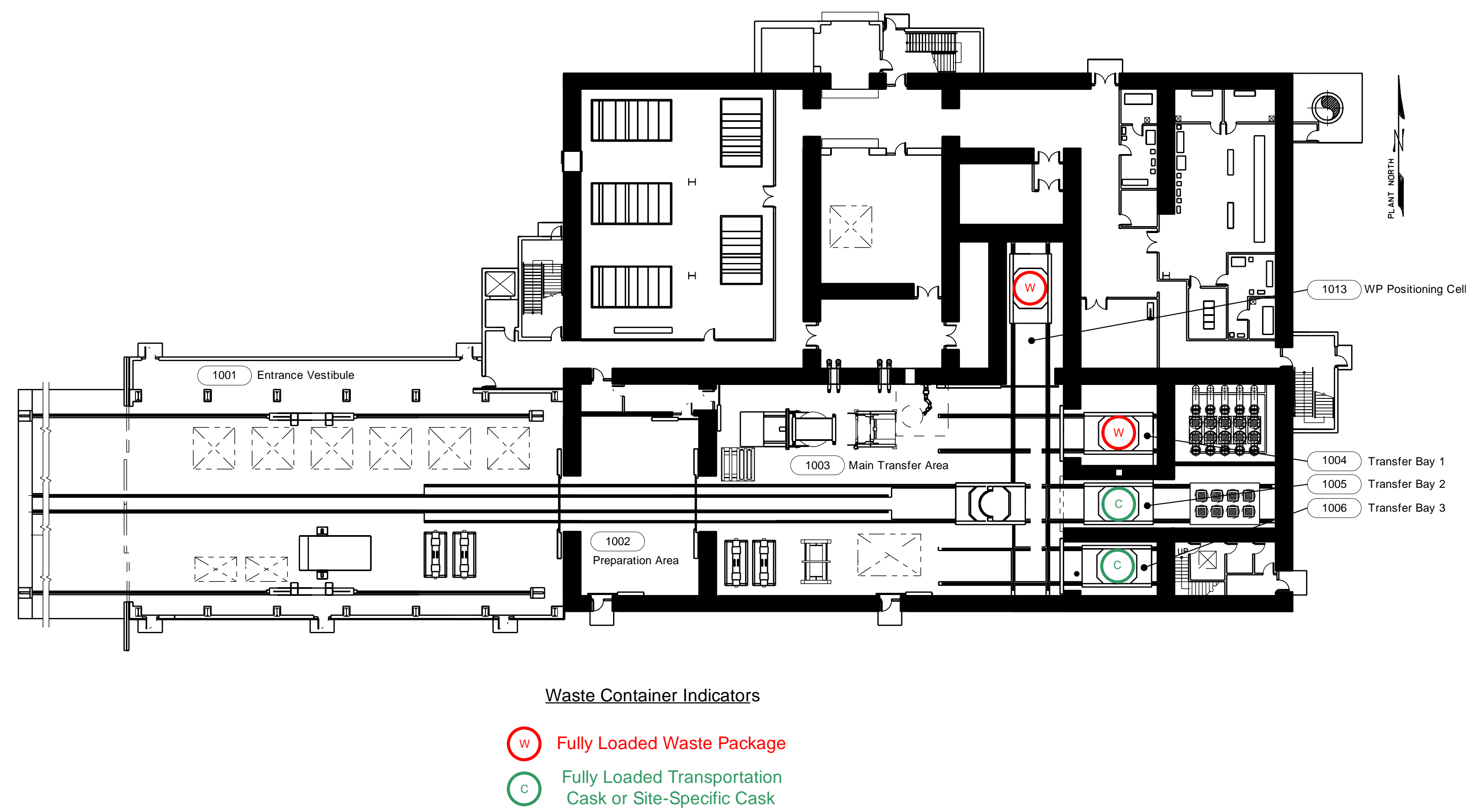

Figure B-3 Maximum Inventory of Casks and Waste Packages with the Fuel Handling Facility 
Fuel Handling Facility Description Document

INTENTIONALY LEFT BLANK 


\section{B.3 Facility Drawings}

\section{Table B.3 List of Facility Drawings}

\begin{tabular}{|l|l|}
\hline \multicolumn{1}{|c|}{ Document Identifier } & \multicolumn{1}{c|}{ Drawing Title/Reference } \\
\hline 100-C00-MGR0-00101-000 & Geological Repository Operations Area North Portal Site Plan \\
\hline 210-P10-FH00-00101-000 & Fuel Handling Facility General Arrangement Legend and General Notes \\
\hline 210-P10-FH00-00102-000 & Fuel Handling Facility General Arrangement Ground Floor Plan \\
\hline 210-P10-FH00-00103-000 & Fuel Handling Facility General Arrangement Operating Floor Plan \\
\hline 210-P10-FH00-00104-000 & Fuel Handling Facility General Arrangement Mezzanine Plan \\
\hline 210-P10-FH00-00105-000 & Fuel Handling Facility General Arrangement Floor Plan @ Elev +64'-0” \\
\hline 210-P10-FH00-00106-000 & Fuel Handling Facility General Arrangement Plan @ Elev. 84'-0” \\
\hline 210-P10-FH00-00107-000 & Fuel Handling Facility General Arrangement Roof Plan \\
\hline 210-P10-FH00-00108-000 & Fuel Handling Facility General Arrangement Section A \\
\hline 210-P10-FH00-00109-000 & Fuel Handling Facility General Arrangement Section B \\
\hline 210-P10-FH00-00110-000 & Fuel Handling Facility General Arrangement Sections C,D, \& G \\
\hline 210-P10-FH00-00111-000 & Fuel Handling Facility General Arrangement Sections E,F, \& H \\
\hline
\end{tabular}




\section{INTENTIONALY LEFT BLANK}




\section{APPENDIX C: LIST OF FACILITY PROCEDURES}

Procedures affecting this facility shall be listed in future revisions. Detailed operating procedures will not be developed until after construction authorization. 